\section{(A) Check for updates}

Cite this: Dalton Trans., 2018, 47, 5031

Received 27th February 2018,

Accepted 5th March 2018

DOI: $10.1039 / \mathrm{c} 8 \mathrm{dt} 00773 \mathrm{j}$

rsc.li/dalton

\title{
Tin guanidinato complexes: oxidative control of Sn, SnS, SnSe and SnTe thin film deposition $\dagger+$
}

\author{
Ibrahim Y. Ahmet, (DD a Michael S. Hill, (DD *a,b Paul R. Raithby (ID) ${ }^{b}$ and \\ Andrew L. Johnson (iD *a,b
}

\begin{abstract}
A family of tin(॥) guanidinate complexes of the general form [ $\left.\left\{\mathrm{RNC}\left(\mathrm{NMe}_{2}\right) \mathrm{NR}\right\}_{2} \mathrm{Sn}\right]\left(\mathrm{R}={ }^{\mathrm{i}} \operatorname{Pr}(\mathbf{6}), \mathrm{Cy}(\mathbf{7}), \mathrm{Tol}\right.$ (9) and Dipp (10)) and [ $\left.\left.{ }^{t} \mathrm{BuNC}\left(\mathrm{NMe}_{2}\right) \mathrm{N}^{t} \mathrm{Bu}\right\} \mathrm{Sn}\left\{\mathrm{NMe}_{2}\right\}\right]$ (8) have been synthesised and isolated from the reaction of tin(॥) bis-dimethylamide and a series of carbodiimides (1-5). The cyclic poly-chalcogenide compounds [\{CyNC(NMe $\left.\left.)_{N} \mathrm{NCy}_{2} \mathrm{Sn}_{2 \mathrm{Ch}}\right\}\right](\mathrm{Ch}=\mathrm{S}, x=4$ (11); $\mathrm{Ch}=\mathrm{Se}, x=4$ (12), and $\mathrm{Ch}=\mathrm{S}, x=6$ (13)) with $\left\{\mathrm{SnCh}_{x}\right\}$ rings were prepared by the oxidative addition of elemental sulfur and selenium to the heteroleptic stannylene complex [\{CyNC(NMe 2$\left.) \mathrm{NCy}_{2} \mathrm{Sn}\right](7)$ in THF at room temperature. Similarly, reaction of compounds 6 and $\mathbf{7}$ with an equimolar amount of the chalcogen transfer reagents $\left(\mathrm{SC}_{3} \mathrm{H}_{6}\right.$ and $\mathrm{Se}=\mathrm{PEt}_{3}$, respectively) led to the formation of the chalcogenide tin(Iv) complexes [ $\left.\left\{\mathrm{RNC}\left(\mathrm{NMe}_{2}\right) \mathrm{NR}\right\} \mathrm{Sn}(\mathrm{Ch})\right]$ $\left(\mathrm{R}=\mathrm{Cy}: \mathrm{Ch}=\mathrm{S}(\mathbf{1 4}) ; \mathrm{R}={ }^{\mathrm{i}} \mathrm{Pr}, \mathrm{Ch}=\mathrm{Se}(15) ; \mathrm{R}=\mathrm{Cy}, \mathrm{Ch}=\mathrm{Se}(16)\right)$ with terminal $\mathrm{Sn}=\mathrm{Ch}(14$ and 16) and dimeric bridged seleno-tin $\left\{\mathrm{Sn}_{2} \mathrm{Se}_{2}\right\}$ rings (15), respectively. The mono telluro-compounds [ $\left\{\mathrm{RNC}\left(\mathrm{NMe}_{2}\right)\right.$ $\mathrm{NR}\} \mathrm{Sn}(\mathrm{Te})]\left(\mathrm{R}={ }^{\mathrm{i}} \operatorname{Pr}(\mathbf{1 7}) ; \mathrm{R}=\mathrm{Cy}(\mathbf{1 8})\right)$ were similarly prepared by the oxidative addition of elemental tellurium to $\mathbf{7}$ and $\mathbf{8}$, respectively. All of the tin containing compounds have been investigated by multinuclear NMR $\left({ }^{1} \mathrm{H},{ }^{13} \mathrm{C}{ }^{119} \mathrm{Sn}\right.$ and ${ }^{77} \mathrm{Se} /{ }^{125} \mathrm{Te}$, where possible), elemental analysis and single crystal $\mathrm{X}$-ray structural analysis (7, 8, 10-13, 15-18). Thermogravimetric analysis (TGA) was used to probe the possible utility of complexes 6-8, 11-12 and 14-18 as single source Sn and SnCh precursors. The Sn(॥) compounds 6 and 7 have been utilised in the growth of thin films by aerosol-assisted chemical vapor deposition (AACVD) at both 300 and $400{ }^{\circ} \mathrm{C}$. The thin films have been analysed by pXRD, EDS, SEM and AFM and shown to be $\mathrm{Sn}$ metal. Subsequent studies provided film growth at temperatures as low as $200{ }^{\circ} \mathrm{C}$. Similarly, the monochalcogenide systems 14, 16 and 18 have been utilised in the AACVD of thin films. These latter studies provided films, grown at 300 and $400{ }^{\circ} \mathrm{C}$, which have also been analysed by pXRD, Raman spectroscopy, AFM, and SEM and are shown to comprise phase pure SnS, SnSe and SnTe, respectively. These preliminary results demonstrate the potential of such simple guanidinate complexes to act as single source precursors with a high degree of oxidative control over the deposited thin films.
\end{abstract}

\section{Introduction}

Over the past decade significant progress has been made in the synthesis of the p-type IV-VI semiconducting tin(II) chalcogenide materials SnS, SnSe and SnTe. These materials have the potential to be exploited in a range of applications including thermoelectric devices, microelectronics, superconducting crystals, rechargeable batteries and solar cells,

\footnotetext{
${ }^{a}$ Centre for Sustainable Chemical Technologies, Department of Chemistry, University of Bath, Claverton Down, Bath, BA2 7AY, UK

${ }^{b}$ Department of Chemistry, University of Bath, Claverton Down, Bath, BA2 7AY, UK. E-mail: A.L.Johnson@bath.ac.uk, M.S.Hill@bath.ac.uk

$\dagger$ Dedicated to Prof. Paul R. Raithby, an outstanding scientist and exceptional friend and colleague, on the occasion of his retirement.

\$Electronic supplementary information (ESI) available. CCDC 1814512-1814521. For ESI and crystallographic data in CIF or other electronic format see DOI: 10.1039/c8dt00773j
}

because of their semiconductor properties and variable band gaps. ${ }^{1-3}$ The tin mono-chalcogenides 'SnCh' $(\mathrm{Ch}=\mathrm{S}$, Se and Te) have intense absorption across the electromagnetic spectrum, with the ground state phases exhibiting narrow band gaps (Ch = S, $1.1 \mathrm{eV}$ (direct), $1.3 \mathrm{eV}$ (indirect); $\mathrm{Ch}=\mathrm{Se}, 0.9 \mathrm{eV}$ (direct), $1.3 \mathrm{eV}$ (indirect); $\mathrm{Ch}=\mathrm{Te}, 0.18 \mathrm{eV}) .{ }^{4}$ For optoelectronic applications, properties such as charge transfer and charge transport strongly depend on the morphology and crystallinity of the materials i.e. thin films vs. nanocrystals, size and surface quality. ${ }^{5,6}$ Literature over the past two decades shows quite clearly that the most critical and significant aspect of controlling the morphology of both thin films and nanocrystals is the selection of starting molecular precursors. ${ }^{7,8}$ It is this selection that determines subsequent features such as solvent and reaction temperature in the case of nanocrystal formation, and deposition procedure and deposition temperature in the case of thin film chemical vapor deposition (CVD). ${ }^{9}$ 
Lewis et al. have recently reviewed routes to both thin film and nanoparticle IV-VI chalcogenide materials. ${ }^{3} \mathrm{~A}$ key feature in the development of successful precursors for phase pure $\mathrm{Sn}$ (II) chalcogenide materials is the ability to control the oxidation state of the tin during the deposition process, so as to suppress the production of higher oxidation state materials (i.e. $\mathrm{Sn}_{2} \mathrm{~S}_{3} \mathrm{SnS}_{2}, \mathrm{Sn}_{2} \mathrm{Se}_{3}$ and $\mathrm{SnSe}_{2}$ ), the presence of which can be detrimental to the performance of binary Sn(II) chalcogenide materials. ${ }^{3,10}$ The ability to control the formation of these materials is paramount and while large number of ligand systems have been developed in an attempt to do so, only a handful have been successful.

We have recently reported the development of single source precursors, for the exclusive production of phase pure $\mathrm{SnO}^{11,12}$ and $\mathrm{SnS}^{10,13}$ materials respectively, which display unprecedented oxidation state control. These compounds provide the necessary kinetic control over the tin oxidation state through the design of ligand systems which decompose under only mild thermal stimulus. A majority of these compounds are based around the modification of tin(II) bis (dimethylamide) by reaction with isocyanates or thioisocyanates, respectively.

The reactivity of tin(II) amides with other simple heterocumulenes $\mathrm{CO}_{2}$, COS and $\mathrm{CS}_{2}$ has also been the subject of investigation forming a range of products from $\mathrm{Sn}$ (II) alkoxides to Sn(II) carbamates, thio-carbamates and dithiocarbamates, depending on the nature of the metal amide. ${ }^{14-16}$

Guanidinate ligands, $\left[\mathrm{R}-\mathrm{NC}\left(\mathrm{NR}^{\prime} \mathrm{R}^{\prime \prime}\right) \mathrm{N}-\mathrm{R}^{\prime \prime \prime}\right]^{-}$are part of a wider family of $N, N^{\prime}$-bidentate ligands, including formamidinate, amidinate, iso-ureate and triazenide ligands, built around a central $\mathrm{sp}^{2}$-hybridised carbon atom and a Y-shaped planar $\left\{\mathrm{CN}_{3}\right\}$ core. For guanidinate ligands the possibility exists of significant lone-pair interaction and delocalisation of electron density from the $\left\{\mathrm{NR}_{2}\right\}$ substituents into the $\{\mathrm{NCN}\}$ core; any such delocalisation has a substantive effect on the orientation of the both the $\left\{\mathrm{NR}_{2}\right\}$ moiety, as shown in Scheme 1. Due to the variety of both $\left\{\mathrm{NR}^{\prime \prime} \mathrm{R}^{\prime \prime \prime}\right\}$ and $\left\{\mathrm{NR}^{\prime}\right\}$ groups these ligands offer great electronic flexibility due to the variable contributions of the two main resonance forms: 1,3diazaallyl (A in Scheme 1) and iminium-diamide (B in Scheme 1), which are determined by the electronic requirements of the metal. ${ }^{17}$ Moreover, the steric bulk and electronic properties of guanidinate ligands can also be easily adjusted through the judicious choice of the organic substituents (R, R', $\mathrm{R}^{\prime \prime}$ and $\left.\mathrm{R}^{\prime \prime \prime}\right)$. Consequently, these ligands display a rich coordi-

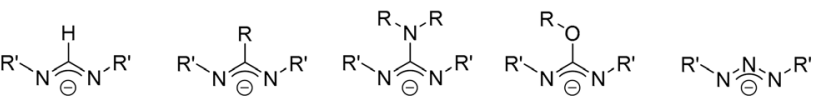

$$
\begin{aligned}
& \text { Formamidinate Amidinate Guanidinate Iso-Ureate Triazenide }
\end{aligned}
$$

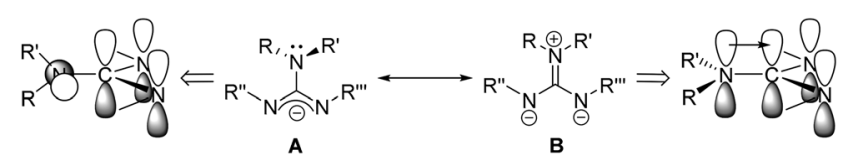

Scheme 1
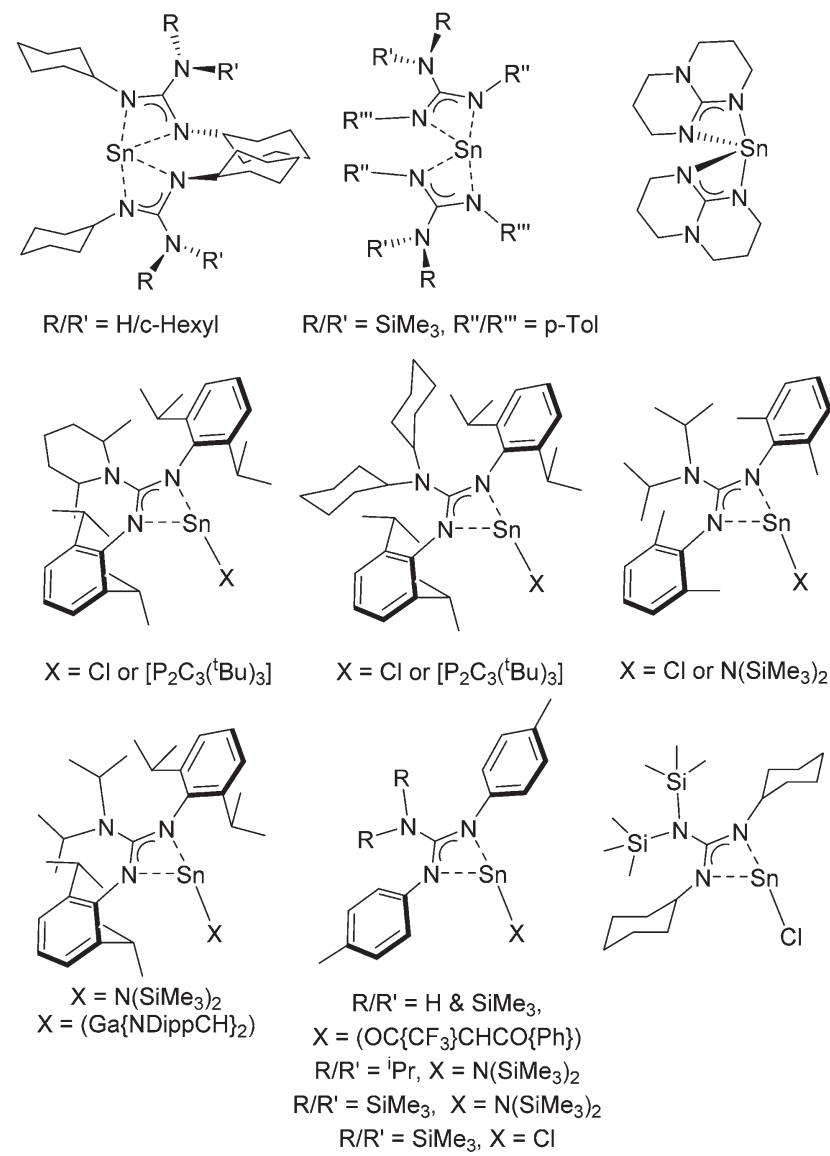

$\mathrm{X}=\mathrm{Cl}$ or $\mathrm{N}\left(\mathrm{SiMe}_{3}\right)_{2}$

$\mathrm{X}=\left(\mathrm{Ga}\{\mathrm{NDippCH}\}_{2}\right.$

Fig. 1 Examples of known Sn(॥) guanidinate complexes.

nation chemistry with most metals. While Sn(II) guanidinate complexes have been known for some time, their numbers are limited to a handful of systems which typically contain sterically bulky groups (Fig. 1). ${ }^{18-24}$

More recently Rưžička et al. have described the insertion reaction of the bulky bis-[bis (trimethylsilyl)amino]tin with a range of carbodiimides to provide the corresponding homo- or heteroleptic tin(II) guanidinate complexes. ${ }^{25}$

Here we describe the reaction of tin(II) bis (dimethylamide) with a series of carbodiimides and the subsequent reactive chemistry of the resultant Sn(II) guanidinate complexes with sources of chalcogenides to form a family of $\mathrm{Sn}$ (Iv) mono and poly-chalcogenide complexes. We also report the remarkable potential of these $\mathrm{Sn}(\mathrm{II})$ and $\mathrm{Sn}(\mathrm{Iv})$ guanidinate complexes to act as single source precursors to thin films of metallic $\operatorname{Sn}(0)$ and tin(II) chalcogenide materials, $\mathrm{SnCh}$ ( $\mathrm{Ch}=\mathrm{S}$, Se or Te), displaying extraordinary oxidative control over the phase distribution of CVD products.

\section{Results and discussion}

\section{Synthesis and solid state studies of Sn(II) guanidinate systems}

Reaction of the carbodiimides 1-5 (Schemes 2 and 3) in THF, with $\mathrm{Sn}\left(\mathrm{NMe}_{2}\right)_{2}$ in a 2:1 molar ratio afforded the tin guanidi- 


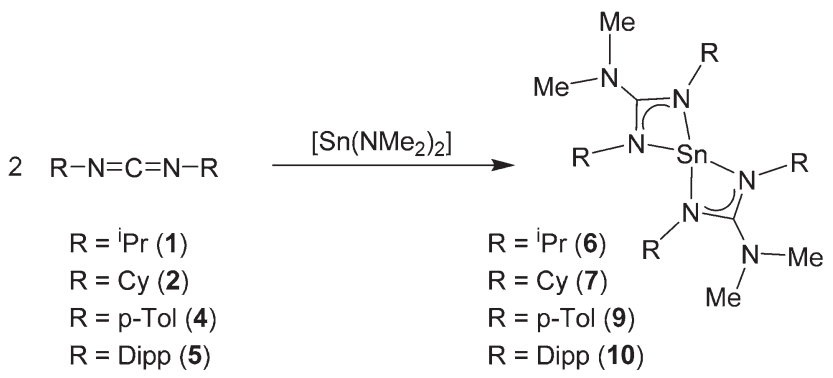

Scheme 2 Synthesis of the homoleptic Sn(II) guanidinate complexes 6-7 and 9-10.

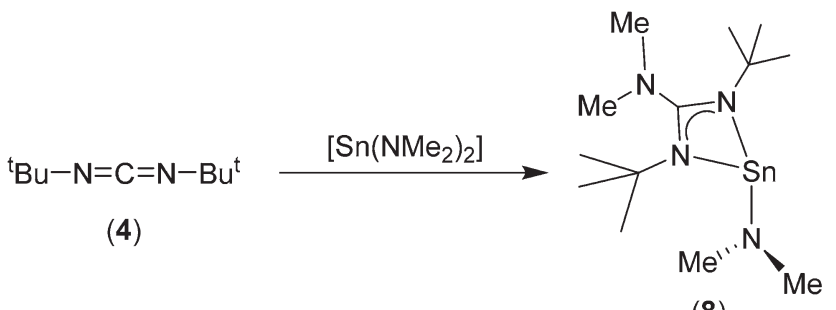

(8)

Scheme 3 Synthesis of the heteroleptic Sn(I) amino guanidinate complex 8 .

nate complexes 6-10 (Scheme 2). Subsequent recrystallisation of the products from hexanes and storage at low temperature $\left(-28^{\circ} \mathrm{C}\right)$ resulted in the formation of crystalline materials suitable for single crystal X-ray diffraction in case of compounds 7-8 and 10. In the case of compounds 6 and 9, microcrystalline powders were isolated. In all cases the products were characterised by solution state NMR $\left({ }^{1} \mathrm{H},{ }^{13} \mathrm{C}\right.$ and $\left.{ }^{119} \mathrm{Sn}\right)$ spectroscopy and elemental analysis.

In the case of complexes 6-7 and 9-10 the ${ }^{1} \mathrm{H}$ NMR spectra contain a single resonance associated with $\left\{\mathrm{NMe}_{2}\right\}$ at $\delta=2.54$ (6), 2.61 (7), 2.26 (9) and 1.96 (10) ppm. Accompanying resonances for the $\{\mathrm{C}-\mathrm{H}\}$ moiety for the isopropyl and cyclohexyl groups can be clearly observed in the respective ${ }^{1} \mathrm{H}$ NMR spectra of 6 and 7 ( $\delta=3.83$ and $3.43 \mathrm{ppm}$ respectively). Similarly, the methyl groups of the $p$-tolyl $(\delta=2.08 \mathrm{ppm})$ and isopropyl groups of the $\{$ Dipp $\}$ substituents ( $\delta=1.18$ (d), 1.25 (d) and $3.11(\mathrm{~m}) \mathrm{ppm}$ ) are also clearly observable.

In all cases the relative integrals of these resonances suggest an insertion into both tin amide bonds, and the formation of homoleptic tin(II) bis-guanidinate complexes (Scheme 2). The ${ }^{13} \mathrm{C}\left\{{ }^{1} \mathrm{H}\right\}$ NMR spectra are also informative, showing a single resonance for the quaternary carbon atom at the core of the guanidinate ligand, with chemical shift values at $\delta=165.9$ (6), 165.8 (7), 161.9 (9) and $160.4 \mathrm{ppm}$ (10). The ${ }^{119} \mathrm{Sn}\left\{{ }^{1} \mathrm{H}\right\}$ NMR spectra also consist of single singlet resonances at $\delta=-382.5(6),-380.9(7)-350.5(9)$ and $-351.4 \mathrm{ppm}$ (10) and are consistent with previously reported homoleptic $\mathrm{Sn}$ (II) guanidinates, ${ }^{25}$ and contrasts with that of the starting material at $\delta=+123.5 \mathrm{ppm}$. The elemental analyses for all com- pounds match the expected values for formation of the tin(II) homoleptic bis-guanidinate systems.

For bis-tbutyl-carbodiimide, 3, insertion into the $\{\mathrm{Sn}-\mathrm{N}\}$ bonds of $\mathrm{Sn}\left(\mathrm{NMe}_{2}\right)_{2}$ appears to occur only once, irrespective of reaction ratio, resulting in the formation of the heteroleptic $\mathrm{Sn}$ (II) amino guanidinate complex, 8 (Scheme 3). We assume that this very selective reaction is a result of either electronic or more probably steric/kinetic factors. The ${ }^{1} \mathrm{H}$ NMR spectrum of 8 clearly shows three singlet resonances in a ratio of $18: 6: 6$ ratio consistent with presence of a single $\left\{\mathrm{Sn}-\mathrm{NMe}_{2}\right\}$ moiety $(\delta=3.18 \mathrm{ppm})$ and a 1,3-di-tertbutyl-2-dimethylguanidinate ligand $\left(\delta=1.18^{26}\right.$ and $\left.2.34\left\{\mathrm{NMe}_{2}\right\} \mathrm{ppm}\right)$. The ${ }^{119} \mathrm{Sn}\left\{{ }^{1} \mathrm{H}\right\}$ NMR spectrum of 8 consists of singlet resonances $(\delta=-121.0 \mathrm{ppm})$. While strikingly different to resonances reported for 6-7 and 9-10, this is consistent with the ${ }^{119} \mathrm{Sn}\left\{{ }^{1} \mathrm{H}\right\}$ NMR previously reported heteroleptic Sn(II) amino guanidinates. ${ }^{25}$ For compounds 6-10, elemental analysis is consistent with the structures deduced by NMR spectroscopy and the solid state observations. It should be noted that complexes $\mathbf{6}$ and $\mathbf{8}$ (low melting solid; m.p. $32{ }^{\circ} \mathrm{C}$ ) are both susceptible to decomposition on standing (under Ar); making them unsuitable as thin film deposition precursors. In contrast, the cyclohexyl derivative, 7, and the aryl derivatives $\mathbf{9}$ and $\mathbf{1 0}$ show no signs of decomposition and can be stored for long periods.

Single crystals of 7, $\mathbf{8}$ and $\mathbf{1 0}$ suitable for single crystal X-ray diffraction analysis were isolated. The result of these studies are consistent with our spectroscopic observations, revealing complexes $\mathbf{7}$ and $\mathbf{1 0}$ to be the four coordinate double insertion products (Fig. 2), and complex 8 to be the three coordinate mono-insertion product (Fig. 3). Selected bond lengths and angles for $\mathbf{7 , 8}$ and $\mathbf{1 0}$ can be found in Table 1 .

Complex 7 crystallises in the triclinic space group $P \overline{1}$ with one molecule in the asymmetric unit cell, whereas complexes 8 and 10 crystallise in the monoclinic space groups $P 2_{1} / a$ and $P 2_{1} / n$ respectively. In the case of complex 8 there are two molecules in the asymmetric unit cell. These complexes share many of the same gross structural features of previously structurally characterised Sn(II) guanidinates. As can be seen in Fig. 2, complex 7 possesses a geometry derived from a distorted trigonal bipyramid in which one equatorial vertex about the $\mathrm{Sn}$ (II) centre is occupied by a stereochemically active lone pair of electrons, and two nitrogen atoms of the guanidinate groups in pseudo-axial positions and two in pseudo-equatorial positions. The substantial distortion of pseudoaxial vector away from linearity is caused by the restricted bite angle of the ligands, typical of other amidinate and guanidinate compounds. The geometry about the Sn(II) centre in $\mathbf{1 0}$ is more accurately described as pseudo square based pyramidal despite the $\mathrm{Sn}-\mathrm{N}$ bond lengths and bite angles in 10 being comparable to related 2,6-disopropylphenyl-substituted amidinate $\mathrm{e}^{27,28}$ and formamidinate ${ }^{29}$ complexes in which the geometries are defined as distorted trigonal bipyramid.

In the case of complex $\mathbf{8}$, mono insertion of a bis- ${ }^{t}$ butyl carbodiimide into a Sn- $\mathrm{NMe}_{2}$ bond results in the formation of the heteroleptic complex $\left[\left\{\mathrm{Me}_{2} \mathrm{NC}\left(\mathrm{N}^{t} \mathrm{Bu}\right)_{2}\right\} \mathrm{Sn}\left(\mathrm{NMe}_{2}\right)\right]$ (Fig. 3) in 

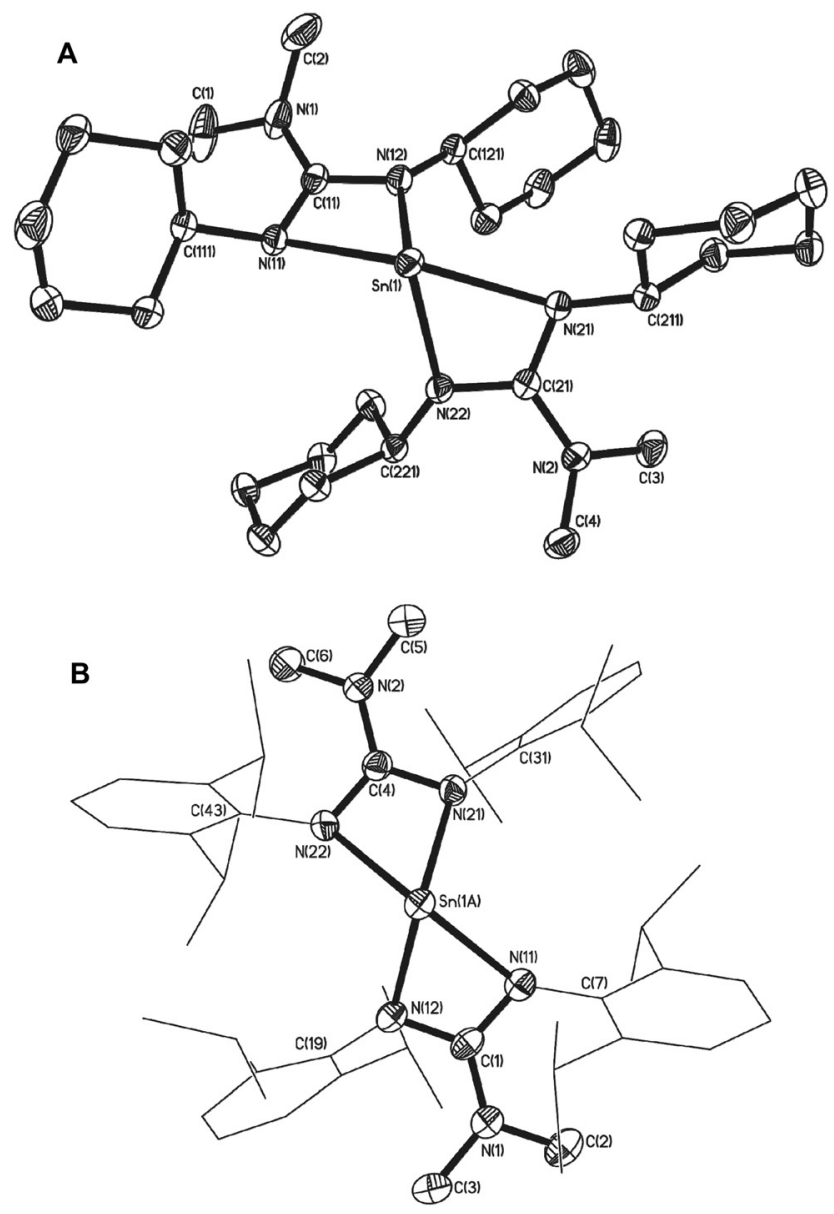

Fig. 2 Molecular structures of complex 7 (A) and complex 10 (B). Hydrogen atoms have been omitted for clarity. Disorder in the 2,6-diisopropyl groups (shown as wire frame: $(C(43)$ and $C(31))$ and at the tin centre have been omitted showing the major component of disorder. Thermal ellipsoids are shown at $50 \%$ probability.

which the metal centre resides in a distorted pseudo tetrahedral environment with one vertex occupied by the stereoactive lone pair of electrons, resulting in a pyramidal array about the metal centre. The tin-guanidinate bonds are comparable to the nominally equatorial $\mathrm{Sn}-\mathrm{N}$ bonds observed in complex 7 with only a very slight asymmetry. The terminal $\mathrm{Sn}-\mathrm{NMe}_{2}$ bond in 8 (i.e. 2.053(2) $\AA$ ) is comparable to that found in $\left[\operatorname{Sn}\left(\mu^{2}-\mathrm{NMe}_{2}\right)\left(\mathrm{NMe}_{2}\right)\right]_{2}(2.06 \AA){ }^{30}$

The planarity of the $\{\mathrm{NCN}\}$ backbone within all three compounds, as indicated by the sum of angles about the $\left\{\mathrm{CN}_{3}\right\}$ backbone approaching $360^{\circ}$, signifies a high degree of $\pi$-electron delocalisation. This delocalisation of the $\pi$-bond in the $\{\mathrm{N}-\mathrm{C}-\mathrm{N}\}$ unit of the ligand is further reflected in the $\mathrm{C}-\mathrm{N}$ bonds [average $\mathrm{C}-\mathrm{N}$ between 1.33-1.34 ̊]. However, this delocalisation appears to be restricted to the diazometallacylic fragment, as indicated by the $\mathrm{C}-\mathrm{N}$ bonds between the exocyclic $\left\{\mathrm{NR}_{2}\right\}$ groups and the $\left\{\mathrm{CN}_{2}\right\}$ units, which show no evidence of shortening and increased multiple bond character.

Strikingly, in the case of both complex $\mathbf{7}$ and $\mathbf{1 0}$ the sum of angles about one of the two nitrogen atoms in the guanidinate ligand, i.e. the axially coordinated nitrogen atoms, are less than $360^{\circ}\left[7: \sum_{\mathrm{N}(11)}=336.42(8)^{\circ}, \sum_{\mathrm{N}(21)}=339.39(8)^{\circ} ; \mathbf{1 0}: \sum_{\mathrm{N}(11)}\right.$

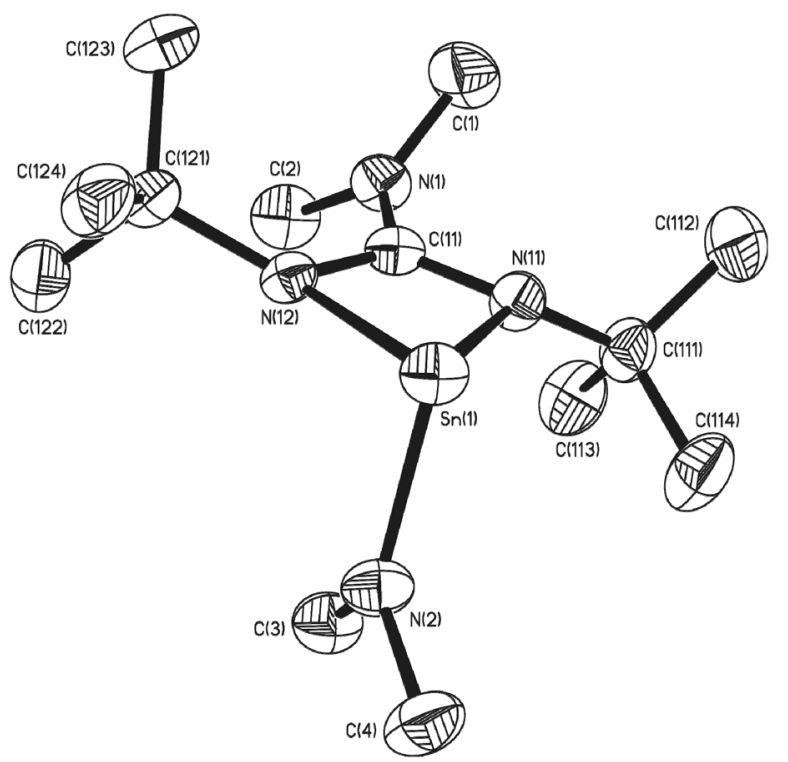

Fig. 3 Molecular structure of one of the two molecules of complex 8 in the asymmetric unit cell. Hydrogen atoms have been omitted for clarity. Thermal ellipsoids are shown at $50 \%$ probability. 
Table 1 Selected bond lengths $(\AA)$ and bond angles $\left({ }^{\circ}\right)$ for complexes 7 , 8 and 10
7

Bond lengths

$\operatorname{Sn}(1)-\mathrm{N}(11)$

$\operatorname{Sn}(1)-\mathrm{N}(12)$

$\operatorname{Sn}(1)-\mathrm{N}(21)$

$\operatorname{Sn}(1)-\mathrm{N}(22)$

$\mathrm{C}(11)-\mathrm{N}(1)$

$\mathrm{C}(21)-\mathrm{N}(2)$

Bond angles

$\mathrm{N}(11)-\mathrm{Sn}(1)-\mathrm{N}(21)$

$\mathrm{N}(12)-\mathrm{Sn}(1)-\mathrm{N}(22)$

$\mathrm{N}(11)-\mathrm{Sn}(1)-\mathrm{N}(12)$

$\mathrm{N}(21)-\operatorname{Sn}(1)-\mathrm{N}(22)$
10

$\begin{array}{ll}2.4149(12) & \mathrm{Sn}(1 \mathrm{~A})-\mathrm{N}(11) \\ 2.1780(12) & \mathrm{Sn}(1 \mathrm{~A})-\mathrm{N}(12) \\ 2.4149(12) & \mathrm{Sn}(1 \mathrm{~A})-\mathrm{N}(21) \\ 2.1895(12) & \mathrm{Sn}(1 \mathrm{~A})-\mathrm{N}(22) \\ & \\ 1.388(1) & \mathrm{C}(1)-\mathrm{N}(1) \\ 1.392(1) & \mathrm{C}(4)-\mathrm{N}(2)\end{array}$

$2.325(2)$

2.258(3)

2.246(3)

$2.370(3)$

1.362(4)

$1.369(4)$<smiles>CN(C)C1=NN(C2CCCCC2)[Sn]2(N=C(N(C)C)N2C2CCCCC2)N1C1CCCCC1</smiles>

127.90(9)

121.52(9)

58.10(9)

57.54(9)

8

\begin{tabular}{llll}
\hline Bond lengths & & & \\
$\operatorname{Sn}(1)-\mathrm{N}(11)$ & $2.272(2)$ & $\mathrm{Sn}(1)-\mathrm{N}(2)$ & $2.053(2)$ \\
$\operatorname{Sn}(1)-\mathrm{N}(12)$ & $2.214(2$ & $\mathrm{C}(11)-\mathrm{N}(1)$ & $1.380(3)$
\end{tabular}

Bond angles

$\mathrm{N}(11)-\mathrm{Sn}(1)-\mathrm{N}(12) \quad 59.99(8)$

$\left.=340.7(3)^{\circ}, \sum_{\mathrm{N}(21)}=339.9(3)^{\circ}\right]$ indicating a degree of pyramidalisation and $\mathrm{sp}^{3}$ character. In the case of $\mathbf{8}$, this pyramidalisation is even more pronounced, with both nitrogen atoms of the guanidinate displaying angles $<360^{\circ}\left[8: \sum_{\mathrm{N}(11)}=354.1(2)^{\circ}\right.$, $\left.\sum_{\mathrm{N}(12)}=351.1(2)^{\circ}, \sum_{\mathrm{N}(21)}=352.5(2)^{\circ}, \sum_{\mathrm{N}(21)}=354.6(2)^{\circ}\right]$, presumably a result of the steric encumbrance caused by the ${ }^{t} \mathrm{Bu}$ groups, and their proximity to the $\left\{\mathrm{NMe}_{2}\right\}$ moiety.

\section{Oxidative additions to homoleptic Sn(II) guanidinates}

The bis(amido) complexes, $\left[\mathrm{M}\left\{\mathrm{HMDS}_{2}\right](\mathrm{M}=\mathrm{Ge}, \mathrm{Sn} ; \mathrm{HMDS}=\right.$ $\left.\mathrm{N}\left(\mathrm{SiMe}_{3}\right)_{2}\right)$, have been shown to undergo reaction with chalcogenide elements $(\mathrm{Ch}=\mathrm{S}$, Se, Te) to yield the bridged dimers $\left[(\mu-\mathrm{Ch}) \mathrm{M}\{\mathrm{HMDS}\}_{2}\right]_{2} \cdot{ }^{31}$ The reaction of $\mathrm{Sn}(\mathrm{II})$ species with elemental chalcogens are typically unpredictable and can result in a range of systems including complexes containing both bridging and terminal $\left\{\mathrm{Ch}^{2-}\right\}$ fragments as well as $\left\{\mathrm{Ch}_{2}{ }^{2-}\right\}$ and $\left\{\mathrm{Ch}_{4}{ }^{2-}\right\}$ groups. While transition metal complexes containing these types of ligand are numerous, there is a general paucity of examples containing main group metals. Noteworthy exceptions in this area are a series of tin complexes incorporating bulky aryl substituents, e.g., $\mathrm{Tb}(\mathrm{Mes}) \mathrm{Sn}$ $(\mathrm{Ch})_{4}, \quad[\mathrm{~Tb}(\mathrm{Mes}) \operatorname{Sn}(\mu-\mathrm{Ch})]_{2}$ and $\operatorname{Bbt}(\mathrm{Tb}) \operatorname{Sn}(\mathrm{Ch})(\mathrm{Ch}=\mathrm{S}$, Se; Mes = mesityl; $\mathrm{Tb}=2,4,6-\left[\left(\mathrm{SiMe}_{3}\right)_{2} \mathrm{CH}\right]_{3} \mathrm{C}_{6} \mathrm{H}_{2} ; \mathrm{Bbt}=2,6-\left[2^{\prime}-\right.$ $\left.\left.\left(\left(\mathrm{CH}_{3}\right)_{2} \mathrm{CH}\right)_{2} \mathrm{C}_{6} \mathrm{H}_{3}\right]_{2} \mathrm{C}_{6} \mathrm{H}_{3}\right)$ as well as the amidinate complexes $\left[\left\{\mathrm{MeC}(\mathrm{NCy})_{2}\right\}_{2} \mathrm{Sn}(\mathrm{S})\right], \quad\left[\left\{{ }^{t} \mathrm{BuC}(\mathrm{NCy})_{2}\right\}_{2} \mathrm{Sn}(\mathrm{S})\right]$ and $\left[\left\{\mathrm{MeC}(\mathrm{NCy})_{2}\right\}\right.$ $\left.(\mathrm{HMDS}) \mathrm{Sn}\left(\mathrm{S}_{4}\right)\right]$, and more recently the guanidinate complexes $\left[\left\{{ }^{\mathrm{i}} \mathrm{Pr}_{2} \mathrm{~N}(\mathrm{NDipp})_{2}\right\}(\mathrm{HMDS}) \mathrm{Sn}(\mu-\mathrm{Se})\right]_{2}$ and $\left[\left\{{ }^{\mathrm{i}} \mathrm{Pr}_{2} \mathrm{~N}(\mathrm{NDipp})_{2}\right\}\right.$ $\left.\left.(\mathrm{HMDS}) \mathrm{Sn}\left(\mathrm{S}_{4}\right)\right]\left(\mathrm{Dipp}=2,6-\left(\mathrm{CH}_{3}\right)_{2} \mathrm{CH}\right)_{2} \mathrm{C}_{6} \mathrm{H}_{3}\right) \cdot{ }^{32-40}$

Here, the reaction of equimolar amounts $(1: 1)$ of complex 7, with elemental sulfur or selenium powder, in THF (Scheme 4) respectively, results in the low yielding formation and isolation of the new complexes, 11 (10\%) and $12(15 \%)$ as

intense yellow and orange crystals. In both cases, the ${ }^{1} \mathrm{H}$ NMR spectra comprise of single resonances for the $\left\{\mathrm{NMe}_{2}\right\}$ groups [11: $\delta=2.32 \mathrm{ppm}$, 12: $\delta=2.70 \mathrm{ppm}]$ as well as NMR peaks associated with the cyclohexyl groups. Here, unlike the spectra of the starting material, 7, the ${ }^{1} \mathrm{H}$ NMR spectra for 11 and 12 reveals the presence of 2 resonances associated with the $\{\mathrm{CH}\}$ moieties of the bis-cyclohexyl guanidinate ligand, indicating a degree of asymmetry in the product. This asymmetry is further confirmed with an inspection of the ${ }^{13} \mathrm{C}$ NMR spectra for $\mathbf{1 1}$ and 12 respectively, which show the presence of 12 resonances associated with the $\{\mathrm{CH}\}$ and $\left\{\mathrm{CH}_{2}\right\}$ groups on the bis-cyclohexyl guanidinate ligand. The ${ }^{119} \mathrm{Sn}\left\{{ }^{1} \mathrm{H}\right\}$ NMR spectrum of complex 11 displays a single resonances at $\delta=-383 \mathrm{ppm}$. In the case of the selenium derivertive, 12, the ${ }^{119} \mathrm{Sn}\left\{{ }^{1} \mathrm{H}\right\}$ NMR spectra clearly shows coupling between ${ }^{119} \mathrm{Sn}$ and ${ }^{77} \mathrm{Se}$ nuclei with the observation of a well-defined doublet [12: $\delta=$ $-396 \mathrm{ppm},{ }^{2} J_{\text {SnSe }}=3060 \mathrm{~Hz}$ ]. Interrogation of the associated ${ }^{77} \mathrm{Se}$ NMR spectra reveals the presence of two Se environments [12: $\delta=131 \mathrm{ppm}$ and $\left.566 \mathrm{ppm}\left({ }^{2} J_{\mathrm{SeSn}}=306 \mathrm{~Hz}\right)\right]$, only one of which displays evidence of Se-Sn coupling. Elemental analysis of complexes $\mathbf{1 1}$ and $\mathbf{1 2}$ are consistent with the formation of the 1,2,3,4,5-tetrachalcogenastannolane systems $\left[\left\{\mathrm{Me}_{2} \mathrm{NC}(\mathrm{NCy})_{2}\right\}_{2} \mathrm{Sn}\left(\mathrm{Ch}_{4}\right)\right] \mathrm{Ch}=\mathrm{S}(\mathbf{1 1})$, or $\mathrm{Se}(12)$. Although several related structures containing $\left\{\mathrm{SnCh}_{4}\right\}$ rings are known in the literature ${ }^{119} \mathrm{Sn}$ and ${ }^{77} \mathrm{Se}$ NMR data for these species is unreported. ${ }^{32,41}$

Structural parameters for complexes 11, 12 and 13 were determined by single crystal X-ray diffraction. Complexes $\mathbf{1 1}$ and 12 crystallise in the monoclinic space group $C 2 / c$. The asymmetric unit cell of $\mathbf{1 1}$ contains two molecules of complex, as well as one molecule of hexane. The asymmetric unit cell of 12 consists of one half of a molecule of complex and half a molecule of THF. Both molecules are essentially isostructural and show analogous gross structural features. Fig. 4 shows the molecular structure of complex 12 (the molecular structure of 11 is included in the ESI $\$$. Selected bond lengths and angles for complexes $\mathbf{1 1}$ and $\mathbf{1 2}$ are shown in Table 2.

In both complexes the $\mathrm{Sn}(\mathrm{Iv})$ centre exhibits a distorted sixcoordinate geometry consisting of two bidentate guanidinate 


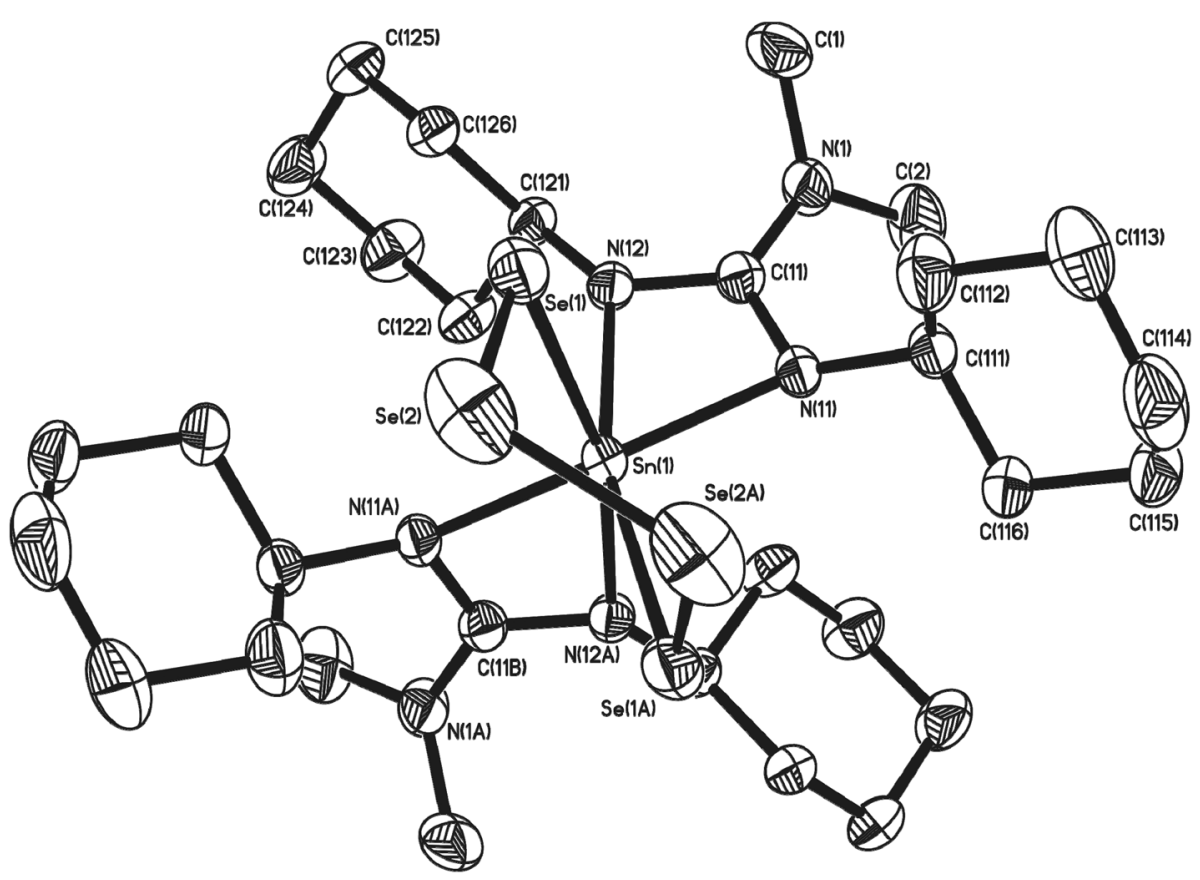

Fig. 4 Molecular structure of complex 12. Solvent of crystallisation (THF) and hydrogen atoms have been omitted for clarity. Symmetry transformations used to generate equivalent atoms: $\# 1-x+1, y,-z+1 / 2 \# 2-x, y,-z+1 / 2$. Thermal ellipsoids are shown at $50 \%$ probability.

Table 2 Selected bond lengths ( $(\AA)$ and bond angles $\left({ }^{\circ}\right)$ for complexes 11 and 12

\begin{tabular}{|c|c|c|c|}
\hline \multicolumn{2}{|l|}{$11^{*}$} & \multicolumn{2}{|l|}{12} \\
\hline \multicolumn{4}{|l|}{ Bond lengths $(\AA)$} \\
\hline $\operatorname{Sn}(1)-\mathrm{N}(12)$ & $2.188(4)$ & $\mathrm{Sn}(1)-\mathrm{N}(12)$ & $2.210(2)$ \\
\hline $\mathrm{Sn}(1)-\mathrm{N}(21)$ & $2.189(4)$ & $\mathrm{Sn}(1)-\mathrm{N}(11)$ & $2.195(2)$ \\
\hline $\mathrm{Sn}(1)-\mathrm{N}(11)$ & $2.193(3)$ & & \\
\hline $\mathrm{Sn}(1)-\mathrm{N}(21)$ & $2.191(4)$ & & \\
\hline $\operatorname{Sn}(1)-S(1)$ & $2.5017(14)$ & $\operatorname{Sn}(1)-\operatorname{Se}(1)$ & $2.6322(3)$ \\
\hline $\operatorname{Sn}(1)-S(4)$ & $2.5285(12)$ & & \\
\hline$S(1)-S(2)$ & $2.0597(19)$ & $\operatorname{Se}(1)-\operatorname{Se}(2)$ & $2.3231(5)$ \\
\hline$S(4)-S(3)$ & $2.0558(19)$ & & \\
\hline$S(2)-S(3)$ & $2.057(2)$ & $\operatorname{Se}(2)-\operatorname{Se}(2 \mathrm{~A})$ & $2.3340(10)$ \\
\hline \multicolumn{4}{|l|}{ Bond angles $\left({ }^{\circ}\right)$} \\
\hline$S(1)-S n-S(4)$ & $92.72(4)$ & $\operatorname{Se}(1)-\operatorname{Sn}(1)-\operatorname{Se}(1 \mathrm{~A})$ & $97.785(16)$ \\
\hline $\mathrm{N}(12)-\mathrm{Sn}(1)-\mathrm{N}(22)$ & $145.29(14)$ & $\mathrm{N}(11)-\mathrm{Sn}(1)-\mathrm{N}(11 \mathrm{~A})$ & $144.70(12)$ \\
\hline $\mathrm{N}(11)-\mathrm{Sn}(1)-\mathrm{N}(21)$ & $106.02(13)$ & $\mathrm{N}(12)-\mathrm{Sn}(1)-\mathrm{N}(12 \mathrm{~A})$ & $100.93(11)$ \\
\hline $\mathrm{N}(11)-\mathrm{Sn}(1)-\mathrm{N}(12)$ & $61.05(13)$ & $\mathrm{N}(11)-\mathrm{Sn}(1)-\mathrm{N}(12)$ & $60.68(7)$ \\
\hline $\mathrm{N}(21)-\mathrm{Sn}(1)-\mathrm{N}(22)$ & $60.93(15)$ & & \\
\hline
\end{tabular}

ligands and two chalcogen atoms of the chelating tetrachalcogenide ligand, $\left[\mathrm{Ch}_{4}\right]^{2-}$. The 5-membered $\left\{\mathrm{SnCh}_{4}\right\}$ rings both reside in a distorted half chair conformation comparable to those observed by others. ${ }^{31,36,39,42}$

A comparison of the Sn-N bond lengths in $\mathbf{1 1}$ and $\mathbf{1 2}$ with those observed in the starting material 7 , shows that with the change in oxidation state, from $\mathrm{Sn}$ (II) to $\mathrm{Sn}$ (Iv) there is a concomitant general reduction in the Sn-N bond lengths. The change in environment also results in a "straightening" of the axial $\mathrm{N}-\mathrm{Sn}-\mathrm{N}$ vector in 7 , from $138.39^{\circ}$ to $145.29^{\circ}(14)$ in $\mathbf{1 1}$, and 144.70(12), in 12 respectively. Whilst analysis of the bonding parameters within the guanidinate ligands of 7 and 11/12, reveals no significant differences in $\{\mathrm{C}-\mathrm{N}\}$ bond lengths or $\{\mathrm{N}-\mathrm{C}-\mathrm{N}\}$ angles, the change in geometry about the $\mathrm{Sn}(\mathrm{Iv})$ metal center results in a small, but significant, increase in the "bite angle" of the guanidinate ligands [11: 61.05(13) and 60.93(15) $)^{\circ}$; 12: $60.68(7)^{\circ} ; c f .7: 58.03(4)^{\circ}$ and $\left.57.86(4)^{\circ}\right]$. As with the parent complex 7 , it is the axial nitrogen atoms which experience the most significant pyramidalisation [11: $\sum_{\mathrm{N}(11)}=$ $348.4(4)^{\circ}, \quad \sum_{\mathrm{N}(12)}=356.5(4)^{\circ}, \quad \sum_{\mathrm{N}(21)}=356.9(4)^{\circ}, \quad \sum_{\mathrm{N}(22)}=$ $\left.350.5(4)^{\circ} ; 12: \sum \mathrm{N}_{(11)}=349.2(1), \sum_{\mathrm{N}(12)}=358.1(1)\right]$.

Subsequent reaction of 7 with $\mathrm{S}$ and Se using a stoichiometric ratio of $1: 4(\mathrm{Sn}: \mathrm{Ch})$, resulted in the isolation of the same crystalline products $\mathbf{1 1}$ and 12, but in higher yields $(11 ; 65 \%, 12 ; 68 \%)$.

During the course of our investigations, co-crystals of the tetrathia complex $\mathbf{1 1}$ and the previously unreported 1,2,3,4,5,6,7-hexathiastannolane complex 13, in which the tin bears a $\left[\mathrm{S}_{6}{ }^{2-}\right]$ hexathia ligand, were also isolated and structurally characterised. Fig. 5 shows the major component, 13 (65\%), of the asymmetric unit cell as determined by single crystal X-ray diffraction. The minor component, 11 (35\%), has been omitted for clarity. Structural parameters such as the general environment about the $\{\mathrm{Sn}$-guanidinate fragment are identical to those observed in $\mathbf{1 1}$. While there is no significant difference within the Sn-S distances $[\operatorname{Sn}(1)-S(1)=2.457(11) \AA$; $\operatorname{Sn}(1)-S(6)=2.571(15) \AA]$ of complex 13, $c f$. 11, there is a significant difference in the $\mathrm{S}-\mathrm{Sn}-\mathrm{S}$ bite angle $[\mathrm{S}(1)-\mathrm{Sn}(1)-\mathrm{S}(6)=$ $\left.107.1(3)^{\circ}\right]$, a value which is consistent with the only other structurally characterised example of a hexathio ligand, $\left[\mathrm{S}_{6}{ }^{2-}\right.$, coordinated to a group 14 metal i.e. [(Dmp)(Dep)Ge $\left.\left(\mathrm{S}_{6}\right)\right](\mathrm{Dmp}$ = 2,6-dimesitylphenyl; Dep = 2,6, diethylyphenyl) ${ }^{41}$ 


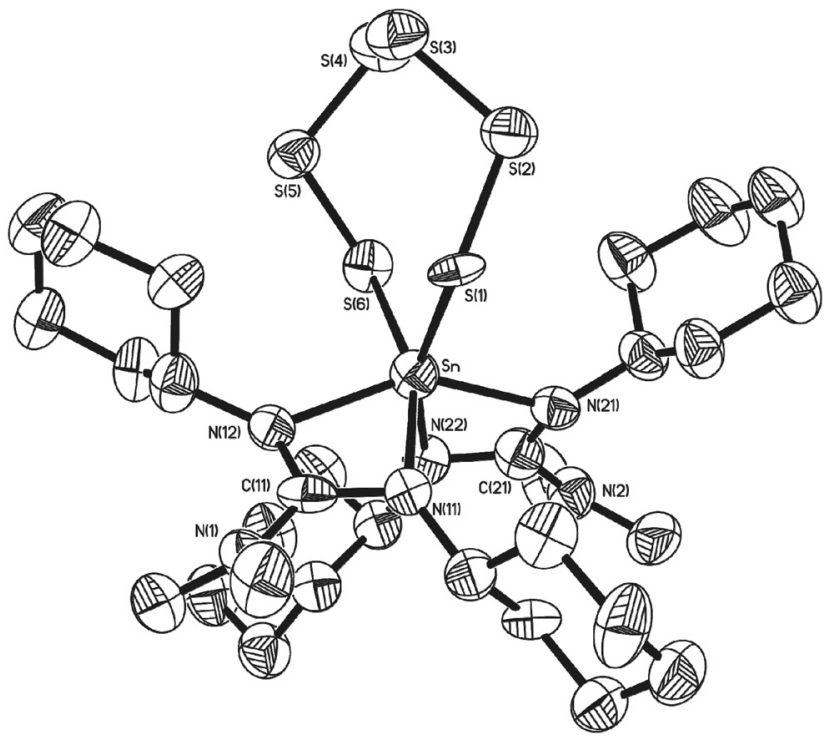

Fig. 5 Molecular structures of complex 13 (65\%). The minor isomer (35\%) with in the asymmetric unit cell (11) has been omitted for clarity. Solvent of crystallisation (THF) and hydrogen atoms have been omitted for clarity. Thermal ellipsoids are shown at $50 \%$ probability.

Examination of the ${ }^{1} \mathrm{H}$ NMR spectra showed no discernable difference between complexes $\mathbf{1 1}$ and $\mathbf{1 3}$ within the mixed sample, with a coincidental overlapping of resonances, perhaps not surprising given the close geometric similarities. However, inspection of both the ${ }^{13} \mathrm{C}$ NMR and ${ }^{119} \mathrm{Sn}$ NMR spectra shows the presence of two sets of resonances, a major and minor set: the ${ }^{119} \mathrm{Sn}\left\{{ }^{1} \mathrm{H}\right\}$ NMR spectra showed resonances at $-383 \mathrm{ppm}$ (minor) and $-393.5 \mathrm{ppm}$ (major), the latter of which we attribute to the hexathiastannolane complex, 13.

On standing, an NMR sample $\left(\mathrm{CD}_{2} \mathrm{Cl}_{2}\right)$ of crystals of the cocrystallised 11 and 13 resulted in the slow release of elemental sulfur, i.e. $\mathrm{S}_{8}$ (identified by single crystal X-ray diffraction), suggesting that a thermodynamic equilibrium exists between 11 and 13, as shown in Scheme 5.

In an attempt to synthesise the mono thio- and selenosystems $\{\mathrm{Sn}=\mathrm{Ch}\}$, complex 7 (and 6) were independently reacted with the single atom transfer reagents propylene sulfide and triethylphosphine selenide respectively (Scheme 6). Reaction of complex 6 with propylene sulfide

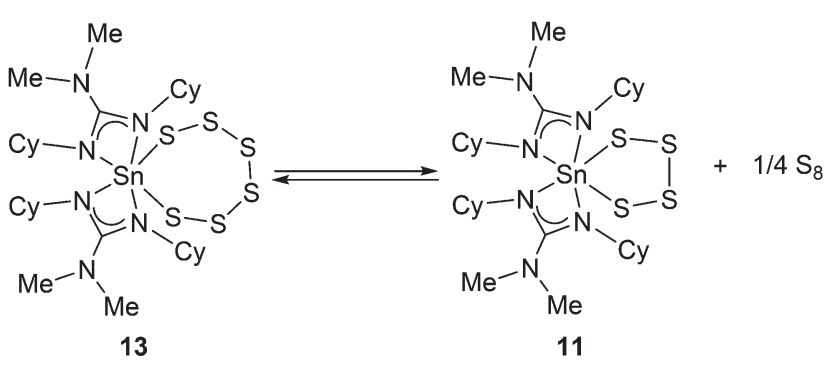

Scheme 5 Equilibrium between the Sn(Iv) guanidinate complexes 11 and 13.

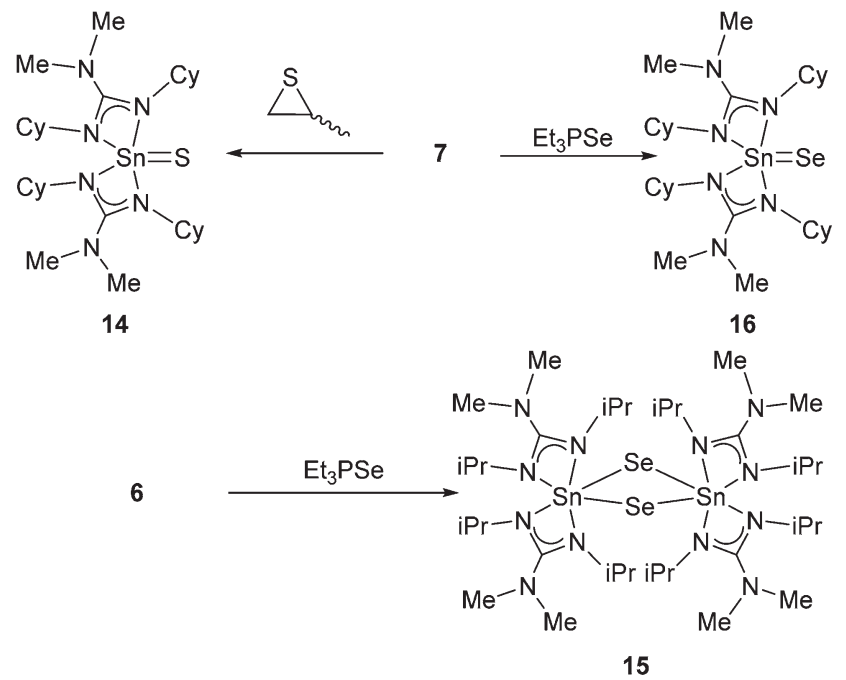

Scheme 6 Synthesis of the heteroleptic Sn(Iv) guanidinate complexes 14,15 and 16.

results in the formation, and isolation, of yellow crystal of $\mathrm{S}_{8}$ (identified by single crystal X-ray diffraction). The precise mechanism by which $\mathrm{S}_{8}$ is formed is unclear, however, ${ }^{1} \mathrm{H},{ }^{13} \mathrm{C}$ and ${ }^{119} \mathrm{Sn}$ NMR spectroscopy of the resulting reaction mixture all suggest decomposition of the complex.

In contrast, reaction of 7 with propylene sulfide in THF under reflux conditions, followed by selective recrystallisation, away from unreacted starting material, results in the formation of a yellow microcrystalline powder (yield $75 \%$ ). ${ }^{119} \mathrm{Sn}$ NMR shows the presence of a single resonance at $\delta=-248 \mathrm{ppm}$, consistent with related species in the literature. ${ }^{33}$ Analysis $\left({ }^{1} \mathrm{H}^{13} \mathrm{C}^{119} \mathrm{Sn}\right.$ and elemental analysis) suggests this product, 14, to be a complex commensurate with the desired $\mathrm{S}: \mathrm{Sn}$ ratio, with an empirical formula of $\left[\left\{\mathrm{Me}_{2} \mathrm{NC}(\mathrm{NCy})_{2}\right\}_{2} \mathrm{Sn}=\mathrm{S}\right]$. A comparable reaction of $\mathbf{6}$ with propylene sulphide showed no evidence of formation of the mono-sulfide complex. Instead, reaction at elevated temperatures resulted in decomposition of 6 .

Reaction of complexes 6 and 7 respectively with the selenium transfer reagent, $\mathrm{Et}_{3} \mathrm{P}=\mathrm{Se}$, results in an obvious color change from yellow to orange, which on work up provides orange/yellow crystals in $72 \%(\mathbf{1 5})$ and $89 \%$ (16) yield. The ${ }^{1} \mathrm{H}$ (and ${ }^{13} \mathrm{C}$ ) NMR spectra for complexes $\mathbf{1 5}$ and 16 are consistent with the related complex already discussed, showing the presence of asymmetry in the guanidinate ligands, as indicated by the presence of two $\{\mathrm{CH}\}$ resonances, in the ${ }^{1} \mathrm{H}$ NMR spectra. The ${ }^{77}$ Se NMR spectra contain single resonance peaks from each system, with a greater downfield shift observed for the selenium centre in $15\left[{ }^{77} \mathrm{Se} \delta=+787 \mathrm{ppm}\right]$, compared to 16 $\left[{ }^{77} \mathrm{Se} \delta=+476 \mathrm{ppm}\right]$, and are comparable to those observed elsewhere. ${ }^{37}$ The ${ }^{119} \mathrm{Sn}\left\{{ }^{1} \mathrm{H}\right\}$ spectra show sharp singlet resonances for $15\left[\delta=-779 \mathrm{ppm}\left({ }^{1} J^{119}{ }_{\mathrm{Sn}-{ }^{77} \mathrm{Se}}=1329 \mathrm{~Hz}\right)\right]$ and 16 $[\delta=-566 \mathrm{ppm}] .^{34,43,44}$ In the latter case, it was not possible to detect ${ }^{77} \mathrm{Se}-{ }^{119} \mathrm{Sn}$ coupling.

Fig. 6 shows the molecular structure of the two selenoderivatives 15 and 16: complex 15 crystallises in the mono- 
A

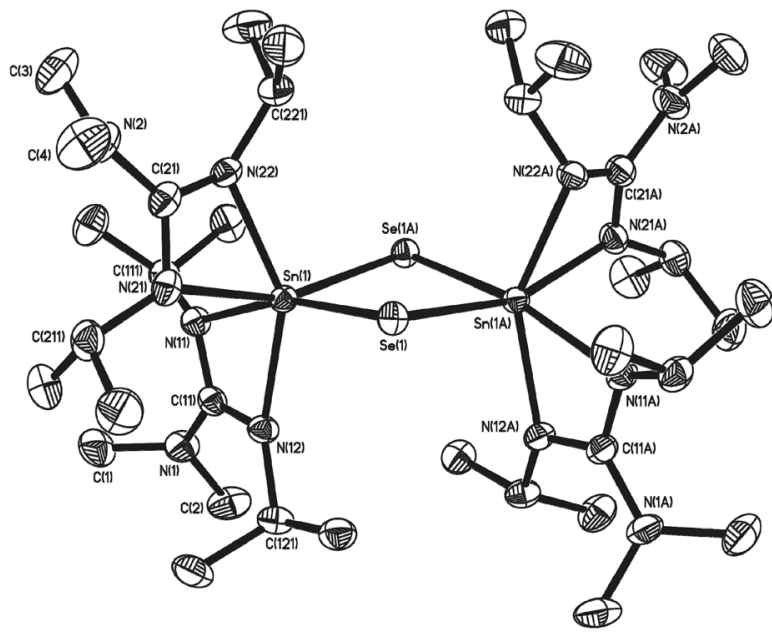

B

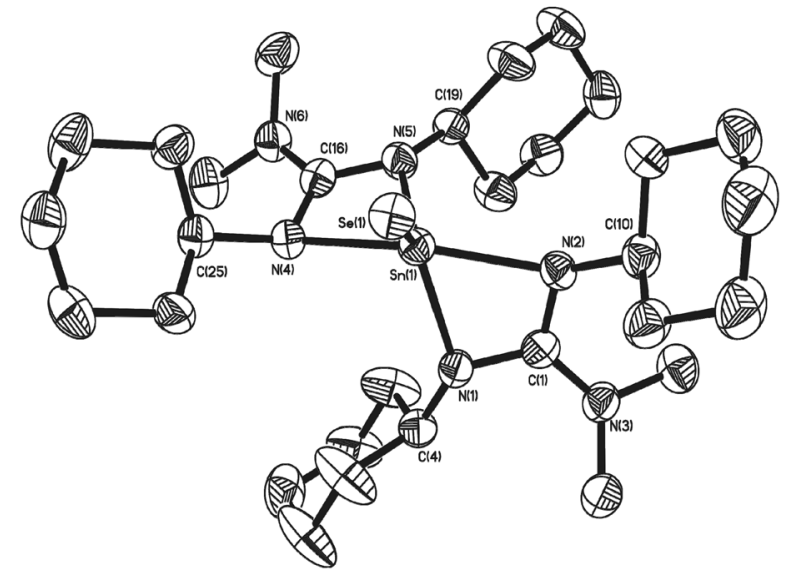

Fig. 6 Molecular structures of the selenium derivatives complex 15 (A) and 16 (B). Hydrogen atoms have been omitted for clarity. Symmetry transformations used to generate equivalent atoms: $1-x, y,-z+1 / 2$.

clinic space group $C 2 / c$ with only half of the dimer present in the asymmetric unit cell. The second half of the dimer is generated by symmetry operators. Complex 16, crystallises in the monoclinic space group $P 2_{1} / a$ with one whole molecule in the asymmetric unit cell. Selected bond lengths and angles pertinent to the discussion of these complexes are shown in Table 3. From Fig. 6 it is clear that the most outstanding feature of complex 15 is its dimeric nature with a $C_{2}$ axis perpendicular to the $\left\{\mathrm{Sn}_{2} \mathrm{Se}_{2}\right\}$ ring. Both $\mathrm{Sn}$ atoms possess pseudo octahedral coordination geometries, with two slightly asym-

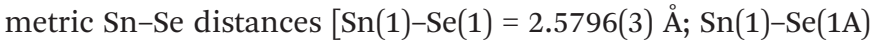
$=2.5982(3) \AA]$. While similar to related $\mathrm{Sn}(\mathrm{IV})-\mu$-Se guanidinate complexes, ${ }^{42}$ these bonds are slightly longer than those found in $\left[\left\{\left(\mathrm{Me}_{3} \mathrm{Si}\right)_{2} \mathrm{~N}\right\}_{2} \mathrm{Sn}(\mu-\mathrm{Se})\right]_{2} \cdot{ }^{31}$ Unlike $\left[\left\{\left(\mathrm{Me}_{3} \mathrm{Si}\right)_{2} \mathrm{~N}\right\}_{2} \mathrm{Sn}(\mu-\mathrm{Se})\right]_{2}$ the $\left\{\mathrm{Sn}_{2} \mathrm{Se}_{2}\right\}$ ring in 15 is not planar, with saddle like geometry such that the Se atoms are raised out of the plane of the Sn atoms by approx. $0.255 \AA$, resulting in an obvious folding of the $\left\{\mathrm{Sn}_{2} \mathrm{Se}_{2}\right\}$ ring at the $\{\mathrm{Se} \cdot \mathrm{Se}\}$ hinge [163.97\% ${ }^{\circ}$. With this folding, the $\mathrm{Sn}-\mathrm{Se}-\mathrm{Sn}$ bond angle [88.636(9) $\left.{ }^{\circ}\right]$ widens, as the $\mathrm{Se}-\mathrm{Sn}-\mathrm{Se}\left[90.253(9)^{\circ}\right]$ bond angles decrease compared to the corresponding angles in $\left[\left\{\left(\mathrm{Me}_{3} \mathrm{Si}\right)_{2} \mathrm{~N}\right\}_{2} \mathrm{Sn}(\mu-\mathrm{Se})\right]_{2}$ [i.e. 88.64(1) ${ }^{\circ}$
Table 3 Selected bond lengths $(\AA)$ and bond angles $\left({ }^{\circ}\right)$ for complex 15 and 16

\begin{tabular}{lrlr}
\hline $\mathbf{1 5}$ & & $\mathbf{1 6}$ & \\
\hline Bond lengths & & & \\
Sn(1)-Se(1) & $2.5796(3)$ & $\mathrm{Sn}(1)-\mathrm{Se}(1)$ & $2.4016(1)$ \\
$\mathrm{Sn}(1)-\mathrm{Se}(1 \mathrm{~A})$ & $2.5982(3)$ & $\mathrm{Sn}(1)-\mathrm{N}(1)$ & $2.168(4)$ \\
$\mathrm{Sn}(1)-\mathrm{N}(11)$ & $2.209(2)$ & $\mathrm{Sn}(1)-\mathrm{N}(2)$ & $2.212(4)$ \\
$\mathrm{Sn}(1)-\mathrm{N}(12)$ & $2.242(2)$ & $\mathrm{Sn}(1)-\mathrm{N}(3)$ & $2.230(4)$ \\
$\mathrm{Sn}(1)-\mathrm{N}(21)$ & $2.265(2)$ & $\mathrm{S})$ & \\
$\mathrm{Sn}(1)-\mathrm{N}(22)$ & $2.183(2)$ & $\mathrm{Sn}(1)-\mathrm{N}(5)$ & \\
& & & \\
Bond angles & & & \\
$\operatorname{Sn}(1)-\mathrm{Se}(1)-\mathrm{Sn}(1 \mathrm{~A})$ & $88.636(9)$ & & \\
$\mathrm{Se}(1)-\mathrm{Sn}(1)-\mathrm{Se}(1 \mathrm{~A})$ & $90.253(9)$ & & \\
& & & \\
$\mathrm{N}(11)-\mathrm{Sn}(1)-\mathrm{N}(12)$ & $59.87(7)$ & $\mathrm{N}(1)-\mathrm{Sn}(1)-\mathrm{N}(2)$ & $61.54(14)$ \\
$\mathrm{N}(21)-\mathrm{Sn}(1)-\mathrm{N}(22)$ & $60.21(8)$ & $\mathrm{N}(4)-\mathrm{Sn}(1)-\mathrm{N}(5)$ & $61.33(14)$ \\
$\mathrm{N}(11)-\mathrm{Sn}(1)-\mathrm{N}(21)$ & $89.29(8)$ & $\mathrm{N}(1)-\mathrm{Sn}(1)-\mathrm{N}(5)$ & $107.31(16)$ \\
$\mathrm{N}(12)-\mathrm{Sn}(1)-\mathrm{N}(22)$ & $146.87(8)$ & $\mathrm{N}(2)-\mathrm{Sn}(1)-\mathrm{N}(4)$ & $144.83(14)$
\end{tabular}

and $95.10(1)^{\circ}$ respectively]. In contrast, reaction of the cyclohexyl-derivative 7 with $\mathrm{Et}_{3} \mathrm{P}=$ Se results in the formation of the monomeric complex 16.

The molecular structure of $\mathbf{1 6}$ (Fig. 6), clearly displays a five coordinate tin centre, in which the coordination environment is provided by the two guanidinate ligands and the selenium atom. With a $\tau$ value of 0.63 , the geometry about the central Sn atom is probably best described as distorted trigonal bipyramidal. The Sn-Se bond distance in 16 [2.4016(1) ̊]], lies between the values of 2.394(1) $\AA$ and 2.148(1) A observed in the pentacoordinate $\mathrm{Sn}(\mathrm{Iv})$ systems $\quad\left[\left(\eta^{4}-\mathrm{Me}_{8} \mathrm{taa}\right) \mathrm{Sn}=\mathrm{Se}\right]^{43}$ and $\left[\left\{\mathrm{C}_{5} \mathrm{H}_{4} \mathrm{NCH}\left(\mathrm{SiMe}_{3}\right)\right\}_{2} \mathrm{SnSe}\right]^{45}$ respectively; this is suggestive of a bond order which lies between the formal resonance structures $\left[\mathrm{L}_{2} \mathrm{Sn}=\mathrm{Se}\right]$ and $\left[\mathrm{L}_{2} \mathrm{Sn}^{+}-\mathrm{Se}^{-}\right]$the calculated values for which are $2.37 \AA$ and $2.57 \AA$ respectively. ${ }^{37}$

While the bite angles for the $\left\{\mathrm{Me}_{2} \mathrm{NC}(\mathrm{NCy})_{2}\right\}$ ligands in $\mathbf{1 6}$ $\left[61.54(14)^{\circ}\right.$ and $\left.61.33(14)^{\circ}\right]$ are not significantly changed compared to related complexes reported here, the slightly smaller bite angles observed in 15 for the $\left\{\mathrm{Me}_{2} \mathrm{NC}\left(\mathrm{N}^{\mathrm{i}} \mathrm{Pr}\right)_{2}\right\}$ ligands $\left[59.87(7)^{\circ}\right.$ and $\left.60.21(8)^{\circ}\right]$ are most probably due to the difference in coordination geometry about the central $\mathrm{Sn}$ atom, rather than any significant electronic effect.

As with previous complexes in this series, the nitrogen atoms within the guanidinate ligands experience some degree of pyramidalisation: in the case of complex $\mathbf{1 6}$ it is the axial nitrogen atoms $\mathrm{N}(2)$ and $\mathrm{N}(4)$ of the trigonal bipyramidal complex, which experience the most significant pyramidalisation $\left[\sum_{\mathrm{N}(1)}=354.41^{\circ} ; \sum_{\mathrm{N}(2)}=342.62^{\circ} ; \sum_{\mathrm{N}(3)}=355.18^{\circ} ; \sum_{\mathrm{N}(4)}=\right.$ $\left.342.74^{\circ}\right]$. For the pseudo octahedral complex 15 it is the equatorial nitrogen atoms and $\mathrm{N}(22)\left[\sum_{\mathrm{N}(22)}=342.26^{\circ}\right]$ and $\mathrm{N}(11)$ $\left[\sum_{\mathrm{N}(11)}=354.41^{\circ}\right]$ which experience the highest degree of pyramidalisation.

Reaction of both 6 and 7, separately, with elemental Te in THF over 3 days at $70{ }^{\circ} \mathrm{C}$, followed by filtration and recrystallisation, results in the formation of large cubic red crystals in yields of $72 \%$ and $86 \%$ respectively. Analysis of the isolated materials by ${ }^{1} \mathrm{H},{ }^{13} \mathrm{C},{ }^{119} \mathrm{Sn}$ NMR spectroscopy and elemental analysis indicate the formation of mono-telluro complexes, 
$\left[\left\{\mathrm{Me}_{2} \mathrm{NC}(\mathrm{NR})_{2}\right\}_{2} \mathrm{Sn}=\mathrm{Te}\right]\left(\mathrm{R}={ }^{\mathrm{i}} \mathrm{Pr}, 17\right.$ or $\left.\mathrm{Cy}, \mathbf{1 8}\right) .{ }^{1} \mathrm{H}$ and ${ }^{13} \mathrm{C}$ NMR spectroscopy shows only relatively small changes in the chemical shifts upon reaction, with resonances associated with the $\left\{\mathrm{NMe}_{2}\right\}$ moieties changing from $\delta=2.54 \mathrm{ppm}$ and $2.61 \mathrm{ppm}$ in 6 and 7 , to $\delta=2.29 \mathrm{ppm}$ and $\delta=2.38 \mathrm{ppm}$ in both 17 and 18 respectively. More significantly, the ${ }^{119} \mathrm{Sn}\left\{{ }^{1} \mathrm{H}\right\}$ spectra show changes in the chemical shift on reaction of 6 and 7 with tellurium from $\delta=-382 \mathrm{ppm}(6)$ to $-918 \mathrm{ppm}(\mathbf{1 7})$ and $\delta=$ $-381 \mathrm{ppm}(7)$ to $-925 \mathrm{ppm}$ (18) respectively, with no discernable ${ }^{125} \mathrm{Te}$ coupling observed. Interestingly, complexes $\mathbf{1 7}$ and 18 respectively, show only one resonance in the ${ }^{1} \mathrm{H}$ NMR spectra associated with the $\{\mathrm{CH}\}$ moieties in the guanidinate ligands. Unfortunately, intensive investigation of the compounds using ${ }^{125} \mathrm{Te}$ NMR spectroscopy failed to reveal the anticipated Te resonances, which may be found over very large chemical shift range. ${ }^{38,46}$

Single crystal X-ray diffraction studies confirm the exclusive formation of the five coordinate systems 17 and 18, which crystallise from toluene in the monoclinic space groups $P 2_{1} / a$ and $P 2_{1} / n$ respectively. The molecular structures of $\mathbf{1 7}$ and 18, shown in Fig. 7, are very similar and clearly display five coordinate $\mathrm{Sn}$ centres, which are closer to trigonal bi-pyramidal than square based pyramidal (17: $\tau=0.54,18: \tau=0.61)$. Selected bond lengths and angles for complexes 17 and 18 are shown in Table 4. The Sn-Te bond distances of 2.6169(3) (17) and 2.6163(4) (18) are both smaller than the sum of the covalent radii of Sn $(1.40 \AA)$ and Te $(1.37 \AA)$, and, as with the terminal SnSe bond in 16, the SnTe bonds in 17 and 18 can be identified as having bond orders which lie between the formal resonance structures $\left[\mathrm{L}_{2} \mathrm{Sn}=\mathrm{Te}\right]$ and $\left[\mathrm{L}_{2} \mathrm{Sn}^{+}-\mathrm{Te}^{-}\right] .{ }^{37}$ The decrease in Sn-N distances (Table 4) in $\mathbf{1 7}$ and 18, compared to the starting materials 6 and 7 (Table 1) are a direct consequence of the change in oxidation state of the Sn centres from Sn(II) to Sn(IV).

As with previous complexes in this series, the nitrogen atoms again occupy the axial positions about the $\mathrm{Sn}(\mathrm{vI})$ centre of the trigonal bipyramidal complexes, which experience the most significant pyramidisation [17: $\sum_{\mathrm{N}(12)}=341.40^{\circ}, \sum_{\mathrm{N}(22)}=$ $\left.343.39^{\circ} ; 18: \sum_{\mathrm{N}(12)}=341.40^{\circ} ; \sum_{\mathrm{N}(21)}=345.97^{\circ}\right]$.

\section{Thermal profile of complexes}

Thermogravimetric analyses (TGA) of complexes 7-8, 11-12 and 14-18 were performed in order to gain insight into relative volatilities and thermal stabilities of the compounds (Fig. 8, 9 and 10 respectively). Table 5 gathers germane data, relating to $\%$-mass residues, expected \%-mass residues, onset temperatures and melting points for these complexes.

Analyses were carried out with an instrument housed in a nitrogen filled purge-box in order to minimise reaction with atmospheric moisture/air. Compounds 6-7 (Fig. 8) were found to undergo mass loss to yield stable residues of between $34.0-16.4 \%$ over the temperature range $92-228{ }^{\circ} \mathrm{C}$. In each case the \% mass of the non-volatile residue is close to that expected for the formation of Sn metal. In the case of complex 7 , a mass residue of $16.4 \%$ ( $v s$. a calculated $19.2 \%$ for $\mathrm{Sn}$ formation) is suggestive of a small degree of volatility (Table 5).
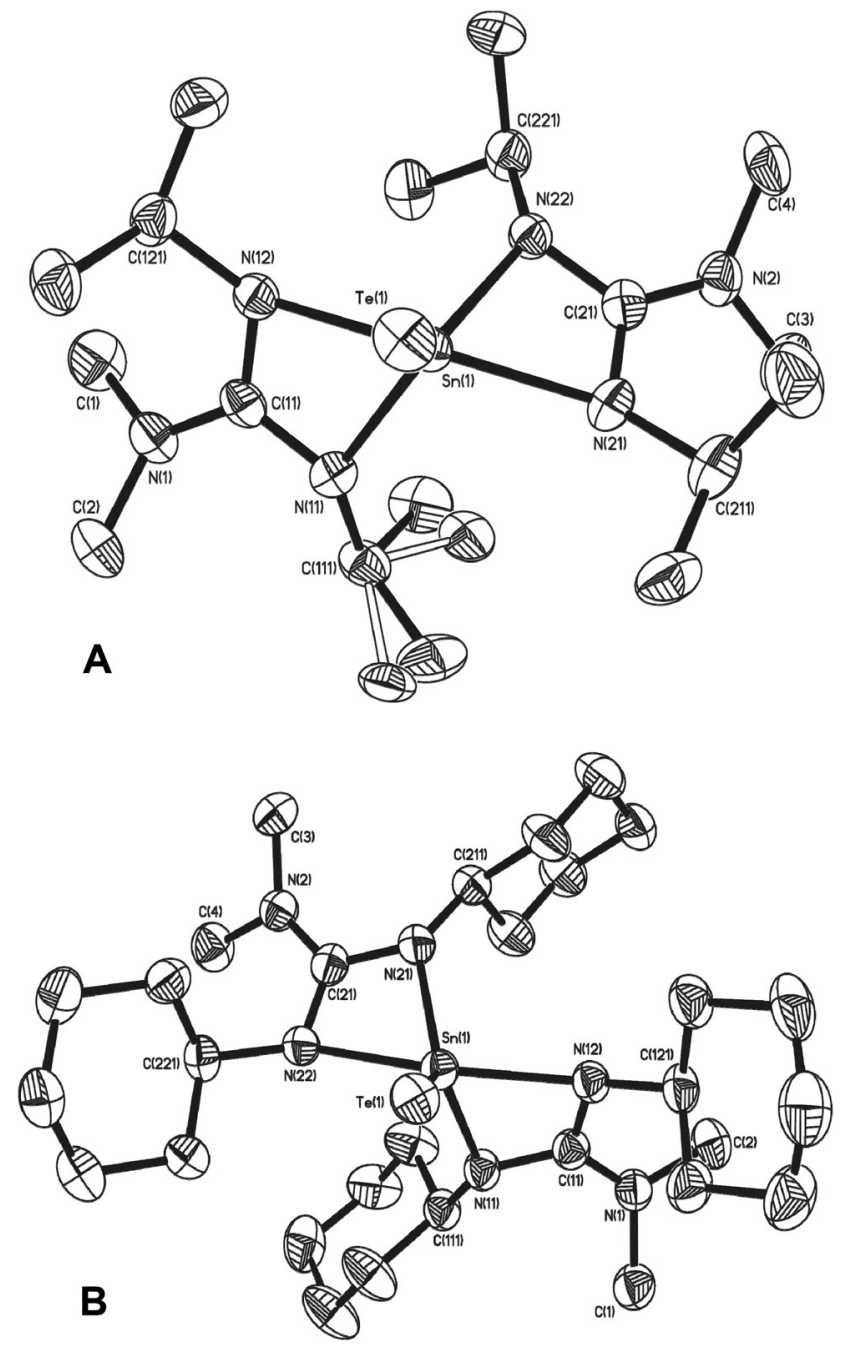

Fig. 7 Molecular structures of complex 17 (A) and 18 (B). Solvent of crystallisation (toluene in 18) and hydrogen atoms have been omitted for clarity.

Table 4 Selected bond lengths $(\AA)$ and bond angles $\left({ }^{\circ}\right)$ for complexes 17 and 18

$17 \quad 18$

Bond lengths

$\operatorname{Sn}(1)-\mathrm{Te}(1)$

$\operatorname{Sn}(1)-\mathrm{N}(11)$

$\mathrm{Sn}(1)-\mathrm{N}(12)$

$\operatorname{Sn}(1)-\mathrm{N}(21)$

$\mathrm{Sn}(1)-\mathrm{N}(22)$

$2.6169(3)$

$2.150(3)$

$2.231(3)$

$2.207(3)$

$2.166(3)$

$\mathrm{Sn}(1)-\mathrm{Te}(1)$
$\mathrm{Sn}(1)-\mathrm{N}(11)$
$\mathrm{Sn}(1)-\mathrm{N}(12)$
$\mathrm{Sn}(1)-\mathrm{N}(21)$
$\mathrm{Sn}(1)-\mathrm{N}(22)$

2.6163(4)

$2.162(3)$

$2.226(3)$

$2.150(3)$

$2.232(3)$

Bond angles

$\mathrm{N}(11)-\mathrm{Sn}(1)-\mathrm{N}(22)$

$\mathrm{N}(12)-\mathrm{Sn}(1)-\mathrm{N}(21)$

$\mathrm{N}(11)-\mathrm{Sn}(1)-\mathrm{N}(12)$

$\mathrm{N}(21)-\mathrm{Sn}(1)-\mathrm{N}(22)$

$111.10(10)$
$142.58(10)$
$61.24(10)$
$61.42(10)$

$\mathrm{N}(11)-\mathrm{Sn}(1)-\mathrm{N}(21)$

$\mathrm{N}(12)-\mathrm{Sn}(1)-\mathrm{N}(22)$

$\mathrm{N}(11)-\mathrm{Sn}(1)-\mathrm{N}(12)$

106.63(13)

143.35(14)

61.28(11)

$61.52(12)$

In the case of the tetrachalcogenastannolane systems $\mathbf{1 1}$ and 12 (Fig. 9) we can clearly see where the tetrathiastannone complex 11 undergoes a well-defined multistep decompo- 


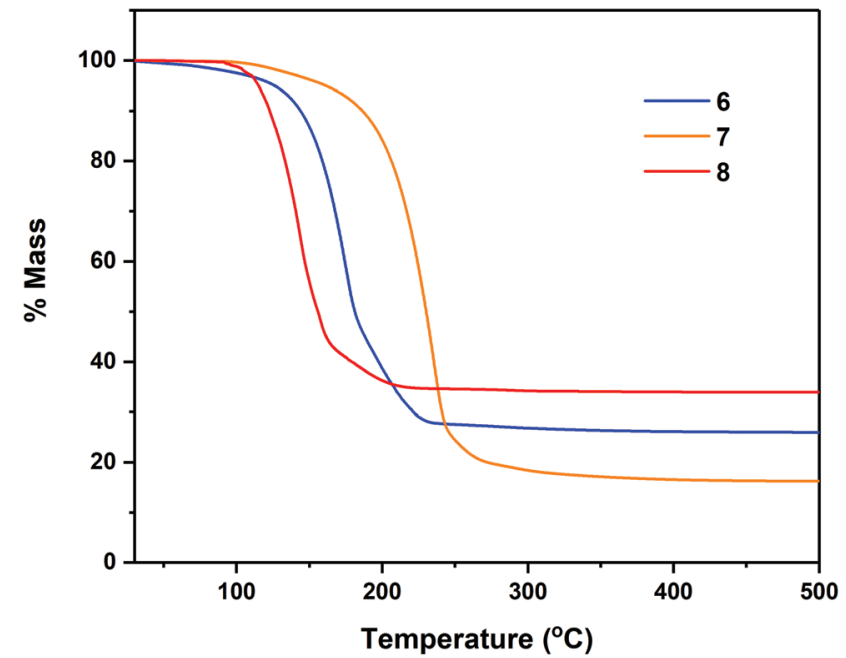

Fig. 8 Thermogravimetric analysis data for complexes 6-7.

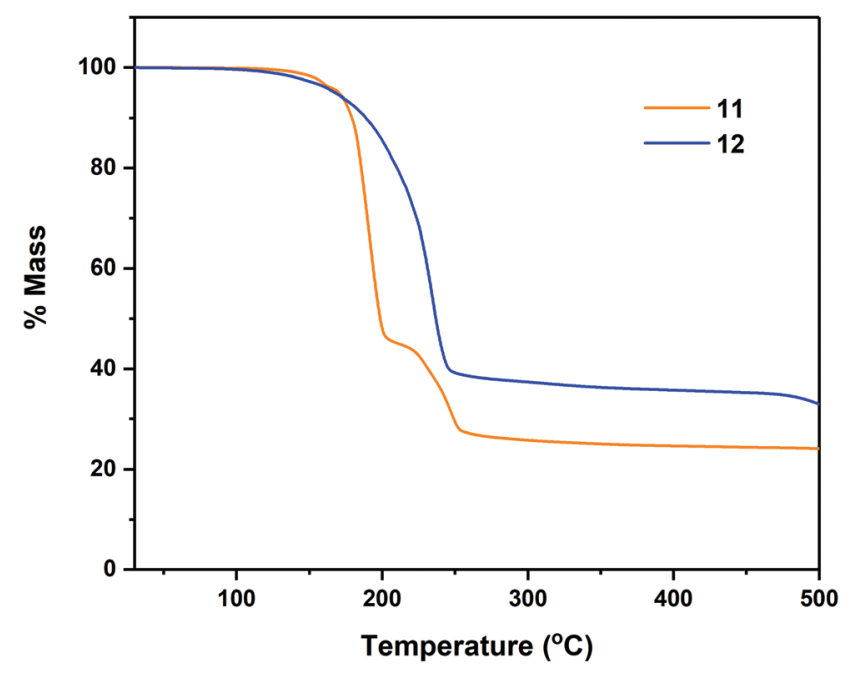

Fig. 9 Thermogravimetric analysis data for complexes 11-12.

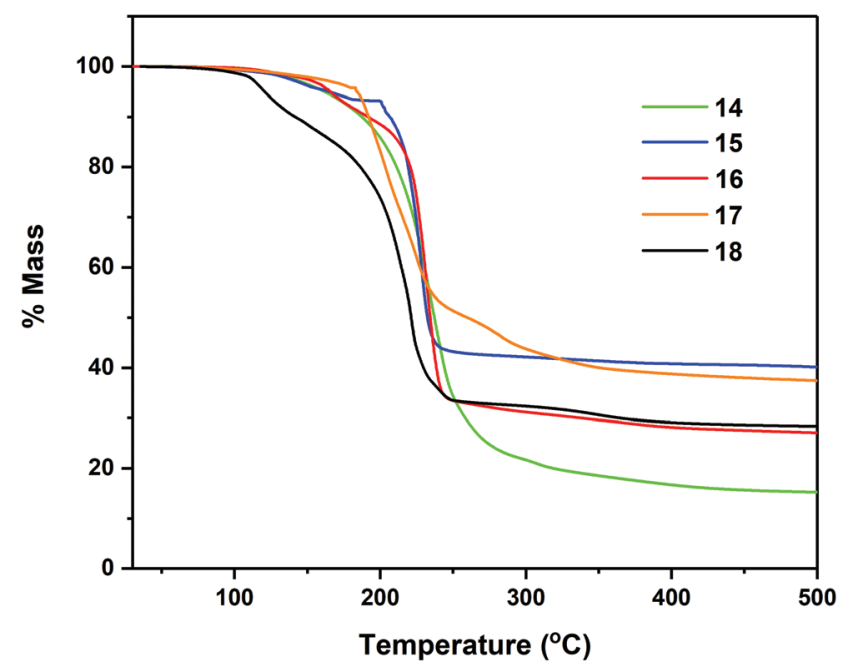

Fig. 10 Thermogravimetric analysis data for complexes 14-18.
Table 5 Expected \% residue, \% of non-volatile residue and onset of volatilisation/decomposition temperature for 6-8, 11-12 and 14-18

\begin{tabular}{lllll}
\hline Precursor & $\begin{array}{l}\text { Expected \% for } \\
\text { residue (residue) }\end{array}$ & $\begin{array}{l}\text { \% Non-volatile } \\
\text { residue (Temp. })\end{array}$ & $\begin{array}{l}\text { Onset } \\
\text { Temp. }\end{array}$ & $\begin{array}{l}\text { Melting } \\
\text { point }\end{array}$ \\
\hline $\mathbf{6}$ & $25.9(\mathrm{Sn})$ & $25.9\left(228^{\circ} \mathrm{C}\right)$ & $115^{\circ} \mathrm{C}$ & $57.5^{\circ} \mathrm{C}$ \\
$\mathbf{7}$ & $19.2(\mathrm{Sn})$ & $16.4\left(205^{\circ} \mathrm{C}\right)$ & $161^{\circ} \mathrm{C}$ & $113^{\circ} \mathrm{C}$ \\
$\mathbf{8}$ & $32.9(\mathrm{Sn})$ & $34.0\left(161^{\circ} \mathrm{C}\right)$ & $92^{\circ} \mathrm{C}$ & $32^{\circ} \mathrm{C}$ \\
& & & & \\
$\mathbf{1 1}$ & $20.1(\mathrm{SnS})$ & $26.1\left(289^{\circ} \mathrm{C}\right)$ & $143^{\circ} \mathrm{C}$ & $118^{\circ} \mathrm{C}$ \\
$\mathbf{1 2}$ & $21.1(\mathrm{SnSe})$ & $37.5\left(295^{\circ} \mathrm{C}\right)$ & $124^{\circ} \mathrm{C}$ & $125^{\circ} \mathrm{C}$ \\
& & & & \\
$\mathbf{1 4}$ & $23.1(\mathrm{SnS})$ & $18.6\left(349^{\circ} \mathrm{C}\right)$ & $121^{\circ} \mathrm{C}$ & $149^{\circ} \mathrm{C}$ \\
$\mathbf{1 5}$ & $41.9(\mathrm{SnSe})$ & $40.7\left(248^{\circ} \mathrm{C}\right)$ & $210^{\circ} \mathrm{C}$ & $124^{\circ} \mathrm{C}$ \\
$\mathbf{1 6}$ & $28.3(\mathrm{SnSe})$ & $27.6\left(248^{\circ} \mathrm{C}\right)$ & $201^{\circ} \mathrm{C}$ & $115^{\circ} \mathrm{C}$ \\
$\mathbf{1 7}$ & $36.7(\mathrm{SnTe})$ & $38.1\left(247^{\circ} \mathrm{C}\right)$ & $180^{\circ} \mathrm{C}$ & $61^{\circ} \mathrm{C}$ \\
$\mathbf{1 8}$ & $33.2(\mathrm{SnTe})$ & $28.3\left(248^{\circ} \mathrm{C}\right)$ & $150^{\circ} \mathrm{C}$ & $101^{\circ} \mathrm{C}$
\end{tabular}

${ }^{a}$ The temperature at which $1 \%$ mass loss has occurred.

sition. In contrast the tetraselenastannolane 12, undergoes a single step decomposition process.

The multi-step decomposition process for $\mathbf{1 1}$ involves an initial mass loss of $\sim 3.5 \%$ between $128.1-164.7^{\circ} \mathrm{C}$. This initial reduction in mass is most likely loss of residual solvent of crystallisation (hexane) trapped in the microcrystalline powder used in the experiment. A second mass loss of $\sim 51.5 \%$ occurs between 164.7-216 ${ }^{\circ} \mathrm{C}$, followed by a third mass loss of $\sim 18.3 \%\left(216.5-278.5{ }^{\circ} \mathrm{C}\right)$ to produce a residue of $\sim 26.1 \%$. While the identity of the volatile fragments are unknown, a residual mass of $26.1 \%$ of the original mass is slightly higher than the value of $20.1 \%$ anticipated in the event of "SnS" formation. In contrast complex 12, which also contains solvent of crystallisation in the solid state ( 1 THF per asymmetric unit cell) shows only a single mass loss event of $\sim 61.4 \%$ between $124.4-295.0^{\circ} \mathrm{C}$, leaving a non-volatile residue of $37.5 \%$ of the original mass, a value significantly higher than the expected value of $\sim 21 \%$, suggestive of "SnSe" formation. The cyclohexylderivatives 14, 16 and 18 all show multi-step decomposition pathways over differing temperature ranges. However, in all three cases the final mass residue is found to be less than that expected, for the formation "SnS", "SnSe" or "SnTe" respectively, indicating a small degree of volatility. For the corresponding Se and Te isopropyl-derivatives (15 and 17), which show a much reduced stability, decomposing at room temperature over time, TGA similarly indicates multi-step decomposition pathways. In the case of 15 , a $\%$ non-volatile mass residue of $40.7 \%$ is only slightly less than the expected value of $41.9 \%$ for "SnSe" formation. Contrastingly, 17 provides a \% non-volatile mass residue $(38.1 \%)$ higher than that expected for "SnTe" formation $(36.7 \%)$.

On the basis of these data, complexes 7, 14, 16 and 18 have been investigated for application in the AA-CVD of phase pure $\mathrm{Sn}(0), \mathrm{Sn}(\mathrm{II}) \mathrm{S}, \mathrm{Sn}(\mathrm{II}) \mathrm{Se}$ and $\mathrm{Sn}(\mathrm{II}) \mathrm{Te}$ thin films respectively, rather than low pressure or atmospheric pressure CVD.

\section{Thin film deposition and analysis}

While AA-CVD has been used by others previously in attempts to produce phase pure SnS with only limited success, ${ }^{47-50}$ 
work specific to our laboratory has highlighted the utility of iso-thioureide $\mathrm{Sn}$ (II) complexes as low temperature AA-CVD precursors for the production of pure Sn(II) sulfide thin films. ${ }^{10}$ In an attempt to apply this approach to other precursors and the production of metallic tin and tin chalcogenide thin films, the stannous guanidinate complex, $\mathbf{6}$ and 7, and the chalcogenide derived stannic guanidinate complexes 14, 16 and 18 have been investigated.

Thin films were initially deposited by AA-CVD on crystalline silicon substrates, under hot wall conditions with a TSI 3076 Constant Output Atomiser apparatus, as previously described, using argon at $20 \mathrm{psi}$ to generate the Aerosol and to act as a carrier gas. ${ }^{10,12,51}$ Utilising a $0.033 \mathrm{M}$ toluene solution, deposition was carried out at $300{ }^{\circ} \mathrm{C}$ and $400{ }^{\circ} \mathrm{C}$, over 90 minutes, to provide a range of thin films. In the case of precursors 6 and 7 thin films with a metallic grey lustre were formed on both glass and c-Si at $300{ }^{\circ} \mathrm{C}$ and $400{ }^{\circ} \mathrm{C}$. Over a period of 2 weeks and exposure to air these shiny metallic coatings tarnished, forming a yellow patina. Storage under an oxygen free atmosphere prevented this yellowing. For precursors 14, 16 and 18 deposition onto glass resulted in an obvious colouration of the surface.

Scanning electron microscope (SEM) images of the thin films produced from precursors 7, 14, 16 and 18 and deposited onto c-Si at $300{ }^{\circ} \mathrm{C}$ and $400{ }^{\circ} \mathrm{C}$ and glass at $400{ }^{\circ} \mathrm{C}$, show noncontinuous surface coverage at both $300{ }^{\circ} \mathrm{C}$ and $400{ }^{\circ} \mathrm{C}$. However, coverage is increased at higher temperatures (Fig. S1: ESII). It was for this reason that only the thin films deposited at $400{ }^{\circ} \mathrm{C}$ were further interrogated by energy dispersive X-ray spectroscopy (EDS).

For the thin films produced from precursor 7, EDS analysis of the films deposited onto c-Si (Table S1: ESI+) shows that the film consists of tin (97.35\%) consistent with the formation of tin metal. For precursors 14, 16 and 18, the ratio of $\mathrm{Sn}$ : Ch was consistent with the formation of a potential $1: 1$ product (albeit $\mathrm{Sn}$ rich in the case of both SnS and SnSe, and Te rich for SnTe; see Table S1, ESI:). Despite low surface coverage pXRD was able to confirm Sn, SnS, SnSe and SnTe, respectively, as the only crystalline materials present in the thin films (Fig. S2: ESI\$).

In an attempt to reduce deposition time and increase surface coverage, the molarity of the toluene precursor solution was increased to $0.08 \mathrm{M}$ and materials deposited at deposition temperatures of 300 and $400{ }^{\circ} \mathrm{C}$ for precursors $\mathbf{6 , 7 , 1 4}$, 16 (only $400{ }^{\circ} \mathrm{C}$ ) and $\mathbf{1 8 .}$

For the stannous guanidinate complexes 6 and 7, thin films with a metallic grey lustre were formed when deposited onto silicon substrates. SEM micrographs of the as deposited thin films reveal superior, and significantly greater coverage, and more densely packed surfaces from precursor $7 \mathrm{cf.} 6$ (Fig. 11). pXRD analysis of the as-deposited thin films clearly show the presence of tetragonal metallic tin (JCPDS No. 89-2958), as indicated by the presence of peaks associated with the [200], [101], [220] and [211] Miller planes for metallic-Sn respectively (Fig. 12)..$^{52}$

Energy dispersive X-ray spectroscopy (EDS) of the thin films deposited onto c-Si from precursor 7 at $400{ }^{\circ} \mathrm{C}$, shows that the

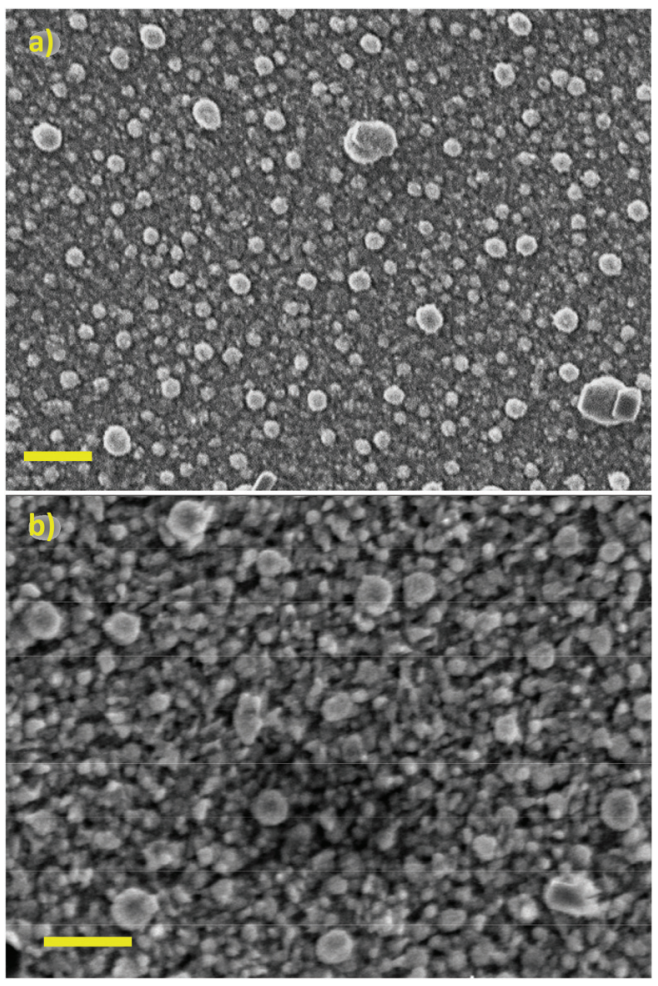

Fig. 11 SEM micrographs of Sn films deposited onto silicon substrates at $400{ }^{\circ} \mathrm{C}$ using precursors 6 (a) or 7 (b) respectively. Scale bar $=1 \mu \mathrm{m}$.

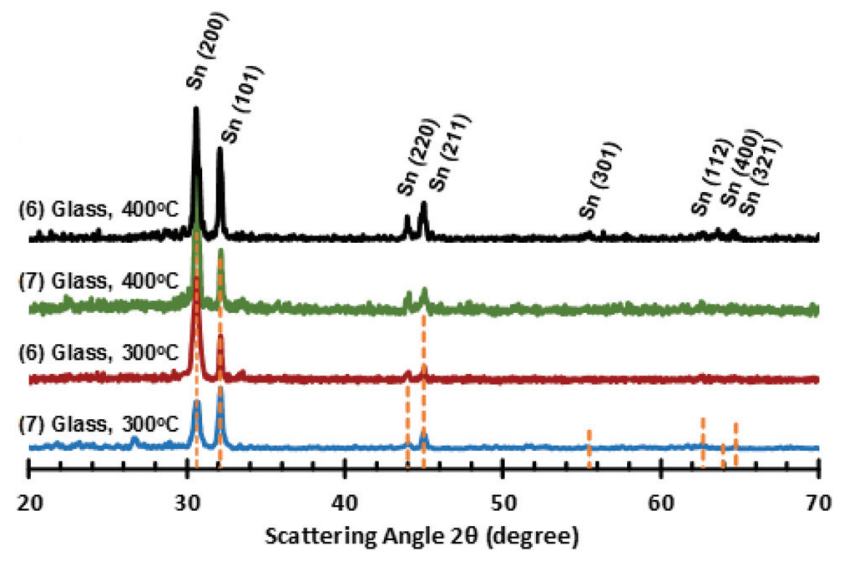

Fig. 12 PXRD patterns for Sn films deposited onto glass at both $300^{\circ} \mathrm{C}$ and $400{ }^{\circ} \mathrm{C}$, from precursors (6) and (7), respectively.

film consists mostly of tin (Sn: 89.36 At\%; Si: 10.64 At\%) although underlying Si-substrate can also be detected. Interestingly, for the thin film deposited from precursor 6 onto glass substrates at $400{ }^{\circ} \mathrm{C}$, EDS shows a significant $\mathrm{At} \%$ of oxygen (Sn: 40.77 At\%; Si: 4.62 At\%; O: 54.61 At\%). The pXRD pattern also shows the presence of peaks associated with $\mathrm{SnO}$ formation. ${ }^{12}$

This observation was confirmed by Raman spectroscopy, with the spectra clearly showing peaks associated with SnO: $\mathrm{B}_{1 \mathrm{~g}}$ and $\mathrm{A}_{1 \mathrm{~g}}$ stretching modes at $105 \mathrm{~cm}^{-1}$ and $203 \mathrm{~cm}^{-1}$ 
respectively. It is presumed that the higher reaction temperature promotes SnO formation. It should be noted that while crystalline Sn metal should not generate a Raman signal, when samples are excited with a $532 \mathrm{~nm}$ laser at powers greater than $1 \%$, the Raman spectra of the thin films begin to show the presence of distinct signals, attributed to $\mathrm{SnO}\left(\mathrm{B}_{1 \mathrm{~g}}\right.$ and $\mathrm{A}_{1 \mathrm{~g}}$ stretching modes), which becomes more intense with time (ESI: Fig. S4 $\ddagger$ ), presumably a result of laser induced reaction between atmospheric $\mathrm{O}_{2}$ and the tin metal. ${ }^{53}$

For complexes 14, 16 and 18, AA-CVD afforded a range of thin films: for complex 14 deposition at both $300{ }^{\circ} \mathrm{C}$ and $400{ }^{\circ} \mathrm{C}$, results in thin films with non-continuous crystalline material deposited over the substrates. SEM images (see Fig. S4: ESI + ) of the thin film deposited at $300{ }^{\circ} \mathrm{C}$ clearly show randomly orientated needles. Contrastingly, at $400{ }^{\circ} \mathrm{C}$ the formation of more triangular block-like structures, from which needle like structures periodically emanate. EDS analysis of both films are consistent with a $\mathrm{Sn}: \mathrm{S}$ ratio close to $1: 1$ (albeit Sn rich, Fig. S5/Table S2: ESI $\ddagger$ ). pXRD analysis (Fig. S6: ESI $\ddagger$ ) was unable to detect strong $\mathrm{SnS}$ peaks deposited onto the substrate at $300^{\circ} \mathrm{C}$.

However, analysis of the thin films deposited at $400{ }^{\circ} \mathrm{C}$ shows the presence of peaks associated with the deposition of orthorhombic $\alpha$-SnS. ${ }^{10}$

For complex 16, AA-CVD of a $0.08 \mathrm{M}$ toluene solution onto a silicon substrate at $400{ }^{\circ} \mathrm{C}$ produced a reflective thin film with a visible jet-blue colour. At $300{ }^{\circ} \mathrm{C}$, there was no discernible deposition, which was confirmed by SEM analysis. Interestingly, attempts to produce thin films on glass substrate at $300{ }^{\circ} \mathrm{C}$ also failed. Deposition at $400{ }^{\circ} \mathrm{C}$, on glass, provided a non-uniform thin film with a non-reflective matt orange/ amber colour. SEM images of the thin films grown on c-Si and glass substrate are shown in Fig. 13. Films grown onto c-Si substrates appear flat and generate a complete and uniform film coverage (Fig. 12A). Subsequently it was not possible to determine the crystallite size within the films deposited onto silicon from either SEM or AFM analysis since the samples consist of highly smooth surfaces $(\mathrm{Rms}=1.94 \mathrm{~nm}$ ) (Fig. S8: ESI $\$$ ) and no observable grain boundaries.

At first sight it appeared that deposition was unsuccessful, however EDS measurements (ESI tin and selenium across the sample surface in an approximate $1: 1$ stoichiometry. Furthermore, closer examination of the substrate edge (Fig. 12B) presents morphological features such as cracks, delamination, and fractures, which makes it possible to clearly visualise the deposited film and measure its thickness. Cross section SEM analysis of the thin film interface shows that the films to be approximately $\sim 70 \mathrm{~nm}$ thick. Inspection of the micrographs of the thin films deposited onto glass (D-F) in Fig. 12, reveal a very different morphology and much rougher surface $(\mathrm{Rms}=11.3 \mathrm{~nm})$. SEM images show the presence of dispersed nano-crystalline structures. (Fig. 12D-F): crystallites are $\sim 1-2 \mathrm{~nm}$ by $\sim 4-5 \mathrm{~nm}$, with a protruding length of up to $\sim 100 \mathrm{~nm}$. EDS analysis show these crystallites consist of tin and selenium in an approximate 1:1 stoichiometry, as expected for SnSe deposition.

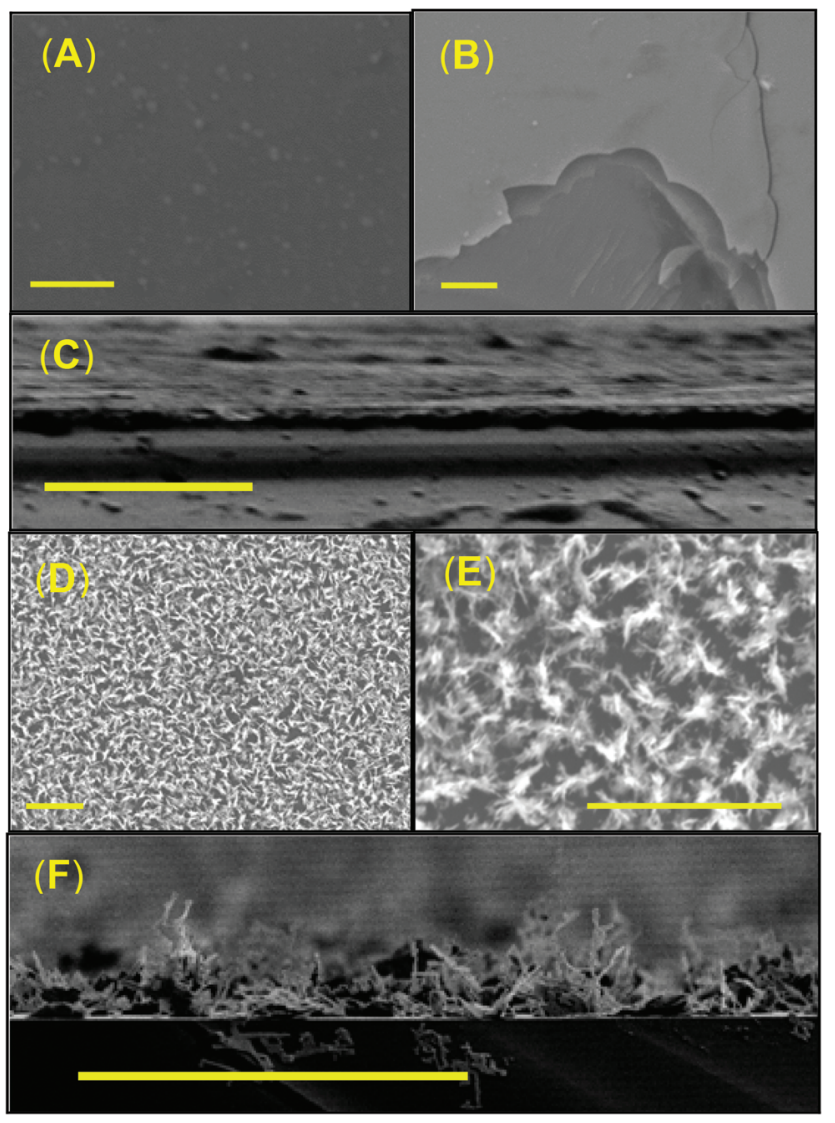

Fig. 13 SEM micrographs of $\alpha$-SnSe thin films deposited onto (A-C) silicon and glass $(\mathrm{D}-\mathrm{F})$ at $400{ }^{\circ} \mathrm{C}$ using precursor 12 . Scale bars $=$ $0.5 \mu \mathrm{m}$.

These observations rationalise the optical appearances of the two samples: for uniform "flat" films deposited onto silicon a reflective 'jet-blue' coating is observed. Films grown onto glass are non-reflective, uniform with an orange/amber matt appearance. The unambiguous differences of "SnSe" film growth mechanism on c-Si and $\mathrm{SiO}_{2}$ are attributed to differing surface/precursor interactions and subsequent growth mechanisms. For both thin films Raman spectroscopy and pXRD analysis confirm the production of SnSe (Fig. 14), specifically the phase pure orthorhombic (Pnma) $\alpha$-SnSe phase (JCPDS: 48 1224). ${ }^{54}$ The Raman spectra of the films grown at $400{ }^{\circ} \mathrm{C}$ do show the presence of a very weak and broad peak at $187 \mathrm{~cm}^{-1}$ which could correspond to the $\mathrm{A}_{1 \mathrm{~g}}$ mode of $\mathrm{SnSe}_{2} \cdot{ }^{55}$ However, associated peaks are not observed in the pXRD analysis (Fig. 14).

For precursor 18, thin films grown on glass $\left(300^{\circ} \mathrm{C}\right.$ and $400{ }^{\circ} \mathrm{C}$ ) are reflective with an orange/amber appearance. For thin films grown on silicon $\left(300^{\circ} \mathrm{C}\right.$ and $\left.400{ }^{\circ} \mathrm{C}\right)$ the films are visibly less uniform with a matt like orange appearance to the eye. SEM images of thin films deposited onto glass and silicon at both $300{ }^{\circ} \mathrm{C}$ and $400{ }^{\circ} \mathrm{C}$, are shown in Fig. 15. For thin films deposited onto glass at $300{ }^{\circ} \mathrm{C}$ and $400{ }^{\circ} \mathrm{C}$ and silicon at $300{ }^{\circ} \mathrm{C}$, the thin films are non-continuous and appear to consist of small crystallites. In the case of the thin film de- 

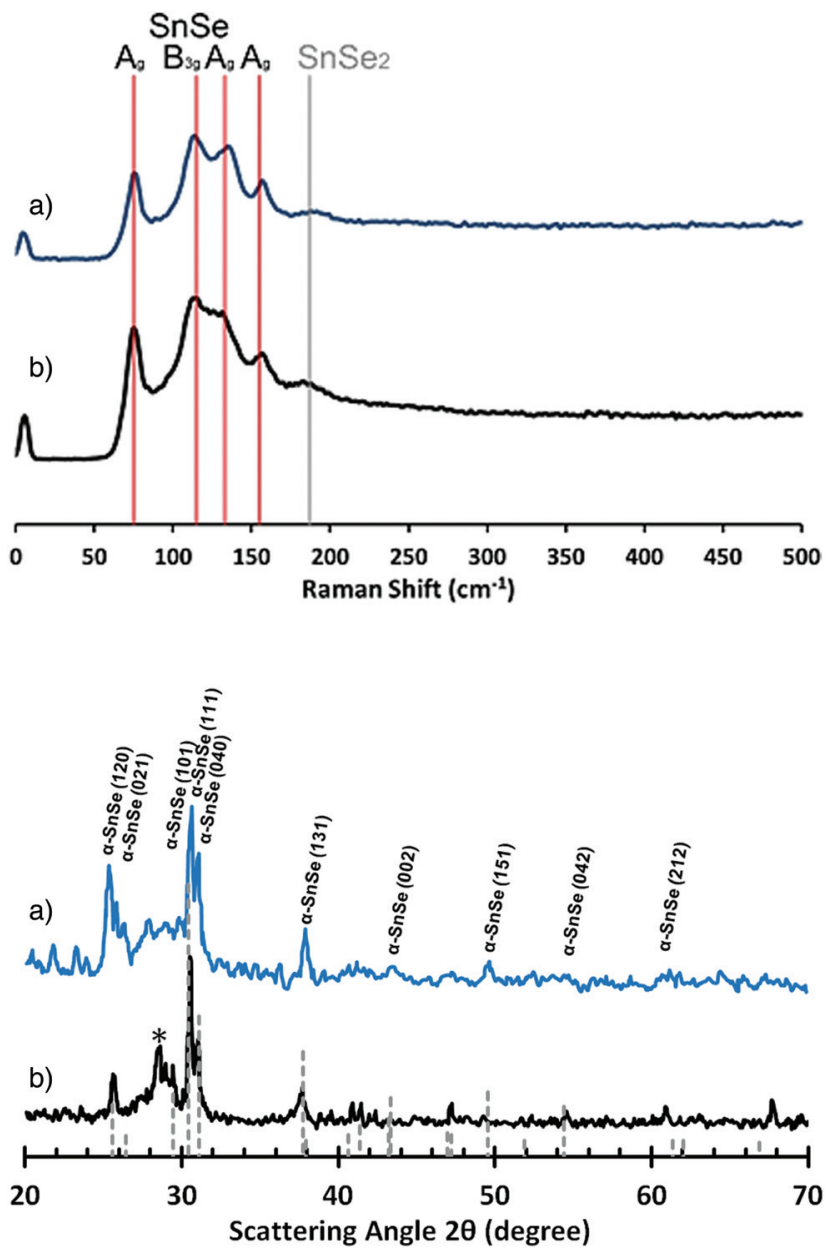

Fig. 14 Raman spectra (top) and PXRD patterns (bottom) for SnSe films deposited from (16) onto glass (a) or silicon (b) at $400{ }^{\circ} \mathrm{C}$. *Unknown peak.

posited onto silicon at $400{ }^{\circ} \mathrm{C}$, however, the film is composed of compacted crystalline spherulites $(\sim 0.1 \mu \mathrm{m}$ in diameter). These observations are consistent with AFM analysis of the films which show RMS values between from 40 to $6 \mathrm{~nm}$ across all the "SnTe" samples (see ESI‡) (Fig. 16).

Analysis by pXRD of all four films ( 300 and $400{ }^{\circ} \mathrm{C}$ on glass and $\mathrm{Si}$ ) show the presence of reflections arising from the [200] and [220] Miller planes associated with cubic-Fm3m SnTe (JCPDS: 48-1224). ${ }^{56}$ However, in the case of the thin film deposited onto glass at both $300{ }^{\circ} \mathrm{C}$ and $400{ }^{\circ} \mathrm{C}$ and onto silicon at $300{ }^{\circ} \mathrm{C}$ the pXRD plot also shown reflections which can be attributed to the presence of trigonal $\mathrm{SnO}$ and $\mathrm{SnO}_{2} \cdot{ }^{57}$ EDS analysis of the pure "SnTe" thin film (glass $/ 400{ }^{\circ} \mathrm{C}$ ) confirms the presence of $\mathrm{Sn}$ and $\mathrm{Te}$ in close to stoichiometric amounts [Sn $=45.85$ at $\%(48.67 \pm 1.71 \mathrm{wt} \%) ; \mathrm{Te}=42.40 \mathrm{at} \%$ $(48.38 \pm 1.71 \mathrm{wt} \%)]$, with only underlying silicon observable in the elemental analysis $[\mathrm{Si}=11.75$ at $\%(2.95 \pm 0.43 \mathrm{wt} \%)]$ (Fig. 17).

To the best of our knowledge similar spherulite production for either SnS, SnSe or SnTe has not previously been noted.

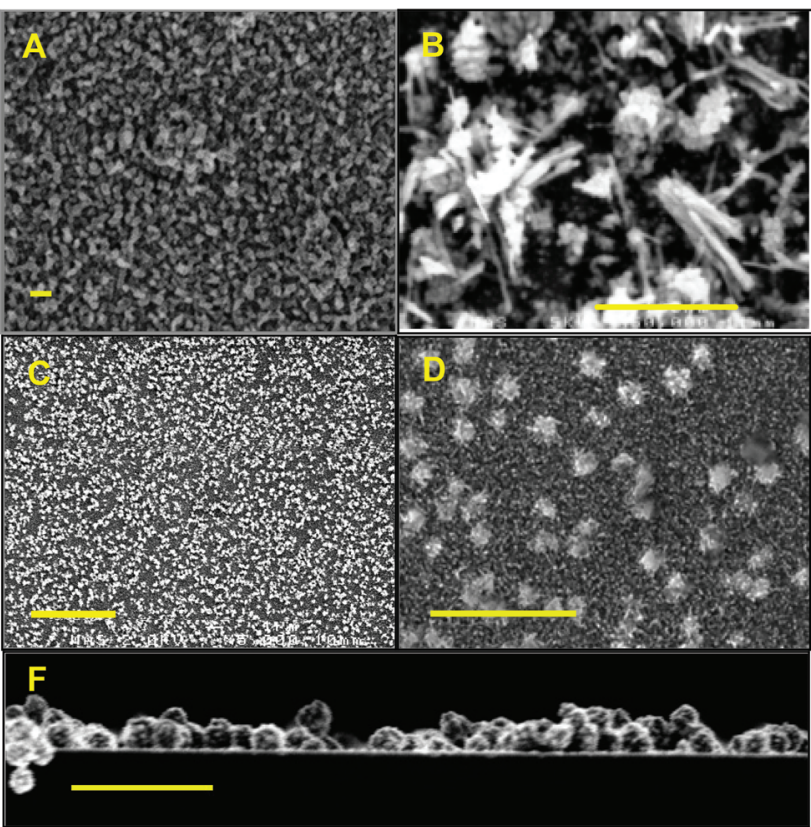

Fig. 15 SEM images of "SnTe" deposited onto glass substrates at $300^{\circ} \mathrm{C}$ (A) and $400{ }^{\circ} \mathrm{C}$ (B) and onto silicon substrates at $300^{\circ} \mathrm{C}$ (C) and $400{ }^{\circ} \mathrm{C}$ (D), respectively. Side-on view of the film deposited on C-Si at $400^{\circ} \mathrm{C}$. Scale bar $=0.5 \mu \mathrm{m}$.

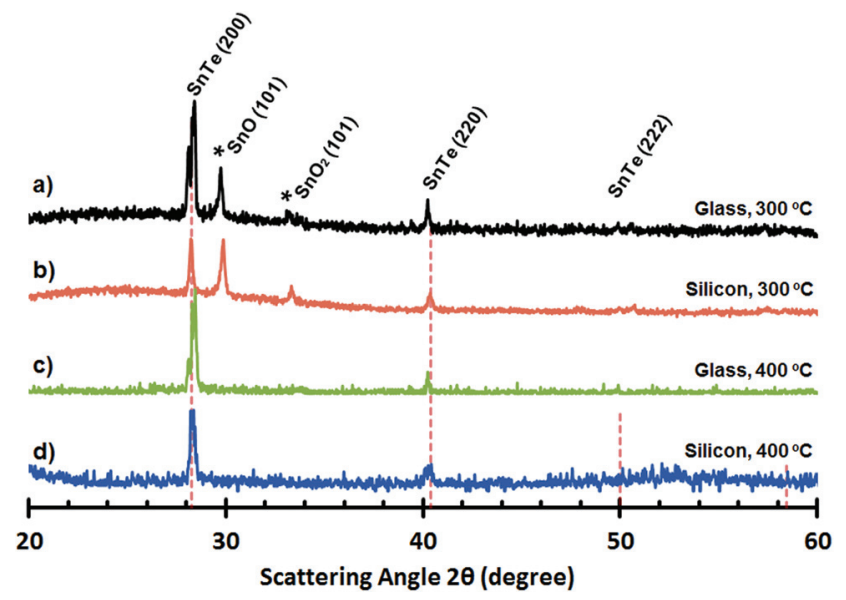

Fig. 16 PXRD plots of "SnTe" deposited from (18) onto glass (a and c) and silicon (b and d) at $300^{\circ} \mathrm{C}$ and $400^{\circ} \mathrm{C}$, respectively.

What we believe is remarkable here is the regularity in size of the SnTe spherulites. Our working hypothesis with respect to spherulite formation is that the precursor $\mathbf{1 8}$ decomposes in a gas phase process, rather than a surface-up growth process. Spherulites thus form in the gas phase, where their nucleation and growth time is limited by mass transport. Furthermore as a certain mass point is approached the spherulites are deposited onto the substrate surface. We are currently further investigating this process for the production of SnTe nanospheres. 


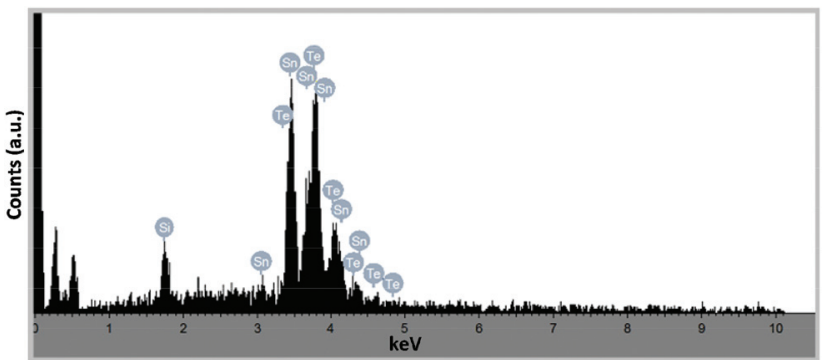

Fig. 17 EDS plot of the thin film produced from precursor 18, onto a silicon substrate.

\section{Conclusions}

Four homoleptic tin(II) guanidinates were prepared by reactions of the appropriate carbodiimides with the stannylene $\left[\mathrm{Sn}\left(\mathrm{NMe}_{2}\right)_{2}\right]$ with high yields under very mild conditions. In the case of the bis- ${ }^{-}$butyl-carbodiimide only the mono insertion product is isolated. The structures of three of these $\mathrm{Sn}$ (II) guanidinate complexes $(7,8$ and $\mathbf{1 0})$ were determined by X-ray diffraction methods. Reaction of the $\mathrm{Sn}(\mathrm{II})$ guanidinate complexes 6 and 7, with the elemental chalcogenides S, Se and Te, and the atom transfer reagents $\mathrm{SC}_{3} \mathrm{H}_{6}$ and $\mathrm{Se}=\mathrm{PEt}_{3}$ respectively (oxidising the metal from the +2 to +4 oxidation state) result in the formation of the cyclic tetrasulphido $\mathrm{Sn}$ (Iv) complex, 11, the cyclic tetraselenido Sn(rv) complex, 13, the $\mu$-seleno tin(Iv) complex bearing a four membered $\left\{\mathrm{Sn}_{2} \mathrm{Se}_{2}\right\}$ ring, 15, and the $\mathrm{Sn}(\mathrm{Iv})$ mono-chalcogenide $\{\mathrm{Sn}=\mathrm{Ch}\}$ complexes, 16, 17 and 18. Based on the results of thermogravimetric analysis, selected complexes i.e. 6-7 and 14, 16 and 18, have been utilised in the growth of thin films by AA-CVD. These latter studies provided film growth at temperatures 300 and $400{ }^{\circ} \mathrm{C}$. The films have been analysed by pXRD, Raman spectroscopy, AFM, and SEM and are shown to comprise primarily of Sn metal (precursors 6 and 7), orthorhombic (Herzenbergite) phase of SnS (14) and SnSe (16), and the cubic phase of SnTe (18). What is remarkable is the observation that the Sn(II) guanidinate complexes (6 and 7) form Sn metal in a two-electron reduction. Similarly the $\mathrm{Sn}(\mathrm{Iv})\{\mathrm{Sn}=\mathrm{Ch}\}$ containing complexes, 14, 16 and 18, also undergo a two-electron reduction to form SnS, SnSe and SnTe, respectively with no observable trace of higher oxidation state $\mathrm{Sn}(\mathrm{rv})$ containing materials, in the thin films (Scheme 7).

Single guanidinate ligands, and the related acetamidimide ligands, are already know to facilitate the one-electron reduction of $\mathrm{Cu}(\mathrm{I})$ to $\mathrm{Cu}(0)$ in the $\mathrm{CVD}$ and $\mathrm{ALD}$ of metallic copper films. ${ }^{58-61}$ On the basis of our observations, it would appear that the reductive behaviour of these ligands is part of a more extensive and general thermal chemistry. Armed with these results we are further investigating the potential of such simple carbodiimide derivatives to act as single source precursors to a wider range of useful metal and metal chalcogenide thin film materials. We are also currently investigating the utility of complexes 14, 16 and 18 in the solvo-thermal synthesis of nanoparticles, which will be reported elsewhere. ${ }^{62}$

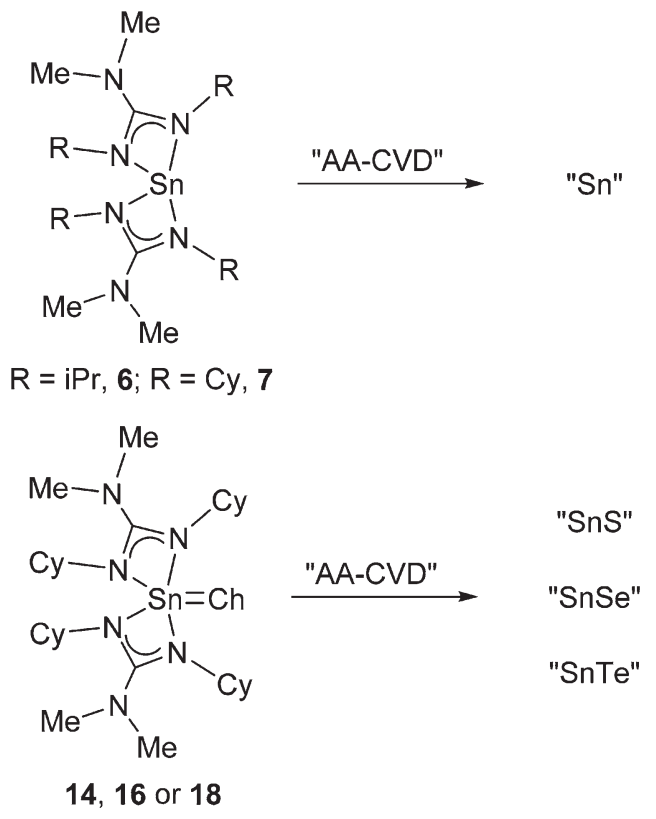

Scheme 7 Oxidative controlled two-electron reduction of Sn(II) and Sn (Iv) guanidinate complexes 6-7, 14, 16 and 18.

\section{Experimental section}

\section{General information}

All reactions were carried out using standard Schlenk line and glovebox techniques under an inert atmosphere of argon and nitrogen, respectively. Tetrahydrofuran (THF) was dried over potassium before isolating via distillation. Hexanes and toluene solvents were dried using a commercially available solvent purification system (Innovative Technology Inc., Amesbury, MA, USA) and all solvents were degassed under argon prior to use. Deuterated benzene $\left(\mathrm{C}_{6} \mathrm{D}_{6}\right)$ and deuterated THF (THF- $d^{8}$ ) NMR solvent were purchased from Fluorochem, Hadfield, U.K., and dried over potassium before isolating via vacuum distillation. All dry solvents were stored under argon in Young's ampules over $4 \AA$ molecular sieves. All reagents were purchased from Sigma-Aldrich and used as supplied. The starting materials, di-isopropylcarbodiimide, di-cyclohexylcarbodiimide, di-tert-butylcarbodiimide, di-tolylcarbodiimide, bis (2,6-diisopropylphenyl)carbodiimide, propylene sulphide, elemental sulphur, selenium and tellurium were purchased from commercial sources and used as received. Tetrakis(dimethylamido)ditin(II) and triethylphosphine selenide were synthesised according to literature procedures.

NMR experiments were conducted in Youngs' tap NMR tubes, prepared and sealed in a glovebox with an argon atmosphere. For all experiments THF- $d^{8}$ was used as the NMR solvent. NMR data were collected at $25{ }^{\circ} \mathrm{C}$ either using a Bruker AV-300 spectrometer operating at $300.22 \mathrm{MHz}\left({ }^{1} \mathrm{H}\right)$, $75.49 \mathrm{MHz}\left({ }^{13} \mathrm{C}\right)$ or a Bruker AV-500 spectrometer at 186.36 MHz $\left({ }^{119} \mathrm{Sn}\right), 95.34 \mathrm{MHz}\left({ }^{77} \mathrm{Se}\right)$ and $157.98 \mathrm{MHz}\left({ }^{125} \mathrm{Te}\right)$ $\mathrm{MHz} \mathrm{MHz}$. Chemical shifts were given in parts per million and referenced internally to residual non-deuterated solvent reso- 
nances. Melting Points were determined using a Stuart SMP10 melting point apparatus. Elemental analyses were performed externally by London Metropolitan University Elemental Analysis Service, U.K.

\section{Synthesies}

Synthesis of 6. $1.51 \mathrm{ml}(1.22 \mathrm{~g}, 9.66 \mathrm{mmol})$ of $N, N^{\prime}$-diisopropyl-carbodiimide (1) was reacted with $1.00 \mathrm{~g}(4.83 \mathrm{mmol})$ of bis-dimethylamino tin(II) dissolved in $30 \mathrm{ml}$ of THF at $-78{ }^{\circ} \mathrm{C}$. After warming to room temperature and stirring the reaction mixture for $2 \mathrm{hrs}$, volatile materials were removed in-vacuo. The residue was extracted with warm hexane, and filtered through Celite to remove insoluble materials. The remaining solution was cooled to room temperature and allowed to recrystallise over two days at $-28^{\circ} \mathrm{C}$, resulting in the formation of a microcrystalline powder, which was isolated via cannula filtration and dried in vacuo. Yield: 1.93 g, 87\%. m.p. $58{ }^{\circ} \mathrm{C}$. Analysis, found (calc. for $\mathrm{C}_{18} \mathrm{H}_{40} \mathrm{~N}_{6} \mathrm{Sn}$ ): C 47.13 (47.07); $\mathrm{H} 8.82$ (8.78); N 18.84 (18.30). ${ }^{1} \mathrm{H}$ NMR (300 MHz $\left.\mathrm{C}_{6} \mathrm{D}_{6}\right) \delta 1.40(\mathrm{~d}, 24 \mathrm{H}$, $\mathrm{CHMe}_{2},{ }^{3} \mathrm{~J}_{\mathrm{HH}} 6.3 \mathrm{~Hz}$ ), 2.54 (s, $12 \mathrm{H}, \mathrm{NMe}_{2}$ ), 3.83 (sept, 4H, $\left.\mathrm{CHMe}_{2},{ }^{3} \mathrm{~J}_{\mathrm{HH}} 6.3 \mathrm{~Hz}\right) .{ }^{13} \mathrm{C}\left\{{ }^{1} \mathrm{H}\right\}$ NMR $\left(75.5 \mathrm{MHz}, \mathrm{C}_{6} \mathrm{D}_{6}\right) \delta 25.9$ $\left(\mathrm{CHMe}_{2}\right), 40.1\left(\underline{\mathrm{C}} \underline{H M e}_{2}\right), 47.7\left(\mathrm{NMe}_{2}\right) 165.9(\mathrm{~N}-\underline{\mathrm{C}}-\mathrm{N}) ;{ }^{119} \mathrm{Sn}\left\{{ }^{1} \mathrm{H}\right\}$ $\operatorname{NMR}\left(186.36 \mathrm{MHz}, \mathrm{C}_{6} \mathrm{D}_{6}\right): \delta_{\mathrm{Sn}}-382.5$.

Synthesis of 7 . In an analogous process to formation of complex 6, 7 was formed by adding a $70 \mathrm{ml}$ THF solution containing $7.5 \mathrm{~g}$ (36.38 mmol) of $N, N^{\prime}$-dicyclohexyl-carbodiimide (2) was added to a $100 \mathrm{ml}$ THF solution containing $7.5 \mathrm{~g}$ (36.06 mmol) of bis-dimethylamino tin(II) at $-78{ }^{\circ} \mathrm{C}$. Recrystallisation yielded yellow crystals of 7 which were isolated via cannula filtration and dried in vacuo. Yield: $15.1 \mathrm{~g}$, $67 \%$. m.p. $113{ }^{\circ}$ C. Analysis, found (calc. for $\mathrm{C}_{30} \mathrm{H}_{56} \mathrm{~N}_{6} \mathrm{Sn}$ ): C 58.19 (58.16); $\mathrm{H} 9.14$ (9.11); $\mathrm{N} 13.60$ (13.57). ${ }^{1} \mathrm{H} \quad \mathrm{NMR}$ $\left(300 \mathrm{MHz}, \mathrm{C}_{6} \mathrm{D}_{6}\right): \delta_{\mathrm{H}} 1.14-2.09(\mathrm{~m}, 20 \mathrm{H}, \mathrm{Cy}), 2.61(\mathrm{~s}, 6 \mathrm{H}$, $\left.\mathrm{NMe}_{2}\right), 3.43\left(\mathrm{~m}, 2 \mathrm{H}, \mathrm{NCHC}_{5} \mathrm{H}_{10}\right) \cdot{ }^{13} \mathrm{C}\left\{{ }^{1} \mathrm{H}\right\}$ NMR $(75.5 \mathrm{MHz}$, $\left.\mathrm{C}_{6} \mathrm{D}_{6}\right): \quad \delta_{\mathrm{C}} 26.5$ (Cy- $\left.\underline{\mathrm{CH}}\right), 27.1$ (Cy- $\left.\mathrm{CH}\right), 36.5$ (Cy$\left(\mathrm{NMe}_{2}\right), 56.6\left(\mathrm{~N}^{-} \mathrm{CHC}_{5} \mathrm{H}_{10}\right), 165.8(\mathrm{~N}-\underline{\mathrm{C}}-\mathrm{N}) ;{ }^{119} \mathrm{Sn}\left\{{ }^{1} \mathrm{H}\right\} \mathrm{NMR}$ $\left(186.36 \mathrm{MHz}, \mathrm{C}_{6} \mathrm{D}_{6}\right): \delta_{\mathrm{Sn}}-380.9$.

Synthesis of 8. A $70 \mathrm{ml}$ THF solution containing $0.47 \mathrm{~mL}$ (0.375 g, $2.41 \mathrm{mmol}$ ) of $N, N^{\prime}$-ditertbutyl-carbodiimide (3) was added to a $30 \mathrm{ml}$ THF solution containing $0.25 \mathrm{~g}(1.20 \mathrm{mmol})$ of bis-dimethylamino tin(II) and stirred at RT for 3 hours. The solvent was removed in vacuo and the remaining oil was treated with $50 \mathrm{ml}$ hexane, then warmed (to $\sim 35{ }^{\circ} \mathrm{C}$ ) and filtered through Celite. The remaining solution was cooled to room temperature and allowed to recrystallize over two days, resulting in large pale yellow crystals of $\mathbf{8}$, which were isolated via cannula filtration and dried in vacuo. Yield: $1.40 \mathrm{~g}, 84 \%$. m.p. $32{ }^{\circ} \mathrm{C}$. decomp. $174{ }^{\circ} \mathrm{C}$ (decomposed to a black solid). Analysis, found (calc. for $\mathrm{C}_{13} \mathrm{H}_{30} \mathrm{~N}_{4} \mathrm{Sn}$ ): $\mathrm{C} 43.24$ (43.24); $\mathrm{H} 8.40$ (8.37); N 15.51 (15.51). ${ }^{1} \mathrm{H}$ NMR (300 MHz, $\left.\mathrm{C}_{6} \mathrm{D}_{6}\right): \delta_{\mathrm{H}} 1.18(\mathrm{~s}$, $\left.18 \mathrm{H}, \mathrm{CMe}_{3}\right), 2.34$ (s, 6H, $\left.\underline{\mathrm{NM}}_{2}\right), 3.18$ (s, 6H, MNMe 2 ). ${ }^{13} \mathrm{C}\left\{{ }^{1} \mathrm{H}\right\}$ NMR $\left(75.5 \mathrm{MHz}, \mathrm{C}_{6} \mathrm{D}_{6}\right): \delta_{\mathrm{c}} 31.7\left(\mathrm{CMe}_{3}\right), 42.7\left(\mathrm{NMe}_{2}\right), 51.8$ $\left(\underline{\mathrm{CMe}}_{3}\right), \quad 54.5 \quad\left(\mathrm{NNMe}_{2}\right), \quad 166.7 \quad(\mathrm{~N}-\underline{\mathrm{C}}-\mathrm{N}) ;{ }^{119} \mathrm{Sn}\left\{{ }^{1}{ }^{1} \mathrm{H}\right\} \quad \mathrm{NMR}$ $\left(186.36 \mathrm{MHz}, \mathrm{C}_{6} \mathrm{D}_{6}\right): \overline{\delta_{\mathrm{Sn}}}-121.0$.

Synthesis of 9. In an analogous process to formation of complex 6, 9 was formed using $0.55 \mathrm{ml}(0.54 \mathrm{~g}, 2.42 \mathrm{mmol})$ of
$N, N^{\prime}$-bis (4-methylphenyl)-carbodiimide (4) and $0.25 \quad \mathrm{~g}$ $(1.20 \mathrm{mmol})$ of bis-dimethylamino tin(II). Work-up, as described above, produced an off white microcrystalline product (9), which was isolated via cannula filtration and dried in vacuo. Yield: $0.61 \mathrm{~g}, 78 \%$. Analysis, found (calc. for $\mathrm{C}_{34} \mathrm{H}_{40} \mathrm{~N}_{6} \mathrm{Sn}$ ): C 62.02 (62.69); H 6.04 (6.19); N 13.12 (12.90). ${ }^{1} \mathrm{H}$ NMR (300 MHz, $\left.\mathrm{C}_{6} \mathrm{D}_{6}\right) \delta 2.08$ (s, $12 \mathrm{H}$, Aryl-Me), 2.22 (s, $\left.12 \mathrm{H}, \mathrm{NMe}_{2}\right), 6.91\left(\mathrm{~d}, 8 \mathrm{H}\right.$, Aryl-CH, $\left.{ }^{3} J_{\mathrm{HH}} 8.2 \mathrm{~Hz}\right), 7.04(\mathrm{~d}, 8 \mathrm{H}$, Aryl-CH, $\left.{ }^{3} J_{\mathrm{HH}} 7.93 \mathrm{~Hz}\right) .{ }^{13} \mathrm{C}\left\{{ }^{1} \mathrm{H}\right\}$ NMR- $\left(75.5 \mathrm{MHz}, \mathrm{C}_{6} \mathrm{D}_{6}\right) \delta 19.6$ (Aryl-Me), $37.8\left(\mathrm{NMe}_{2}\right.$ ), 122.9 (Aryl-C), 128.0 (Aryl-C), 129.2 (Aryl-ㅡ), 144.4 (Aryl- $\underline{\mathrm{C}}$ ), 161.9 (s, $1 \mathrm{C}, \mathrm{N}-\underline{\mathrm{C}}-\mathrm{N}$ ); ${ }^{119} \mathrm{Sn}\left\{{ }^{1} \mathrm{H}\right\}$ NMR $\left(186.36 \mathrm{MHz}, \mathrm{C}_{6} \mathrm{H}_{6}\right) \bar{\delta}_{\mathrm{Sn}}-350.5$.

Synthesis of 10. In an analogous process to formation of complex 6, 10 was formed using $3.51 \mathrm{~g}(9.70 \mathrm{mmol})$ of $N, N^{\prime}$-bis (2,6-diisopropylphenyl)-carbodiimide (5) and $1.00 \mathrm{~g}$ (4.83 mmol) of bis-dimethylamino tin(II). Work-up, as described above, produced colourless crystals of 10. Yield: $4.24 \mathrm{~g}, 94 \%$. Analysis, found (calc. for $\mathrm{C}_{54} \mathrm{H}_{80} \mathrm{~N}_{6} \mathrm{Sn}$ ): C 69.03 (69.59); H 8.82 (8.65); N 9.03 (9.03). ${ }^{1} \mathrm{H}$ NMR $\left(300 \mathrm{MHz}, \mathrm{d}^{8}-\right.$ THF) $\delta 1.18\left(\mathrm{~d}, 12 \mathrm{H}, \mathrm{CHMe}_{2},{ }^{3} J_{\mathrm{HH}} 9 \mathrm{~Hz}\right), 1.25(\mathrm{~d}, 12 \mathrm{H}$, $\left.\mathrm{CHMe}_{2},{ }^{3} \mathrm{JH}_{\mathrm{HH}} 9 \mathrm{~Hz}\right), 3.11$ (m, $\left.4 \mathrm{H}, \underline{\mathrm{C}} \underline{\mathrm{HMe}}{ }_{2}\right), 3.73$ (s, $\left.6 \mathrm{H}, \mathrm{NMe}_{2}\right)$, $7.13(\mathrm{~m}, 2 \mathrm{H}, \mathrm{C}-\mathrm{H}$ aryl $) .7 .26(\mathrm{~m}, 4 \mathrm{H}, \mathrm{C}-\mathrm{H}$ aryl $){ }^{13} \mathrm{C}\left\{{ }^{1} \mathrm{H}\right\}$ NMR$\left(75.5 \mathrm{MHz}, \mathrm{d}^{8}\right.$-THF) $\delta 22.2\left(\mathrm{CHMe}_{2}\right), 24.1\left(\mathrm{CHMe}_{2}\right), 28.5$ $\left(\mathrm{CHMe}_{2}\right) 38.7\left(\mathrm{NMe}_{2}\right), 122.6$ (Aryl-C), 124.4 (Aryl-C), 132.5 (Aryl-C) and 141.9 (Aryl-C), $160.4\left({ }^{\mathrm{N}}-\underline{\mathrm{C}}-\mathrm{N}\right) ;{ }^{119} \mathrm{Sn}\left\{{ }^{1} \mathrm{H}\right\}$ NMR (186.36 MHz, d ${ }^{8}$-THF) $\delta_{\mathrm{Sn}}-351.4$.

Synthesis of 11. $3.19 \mathrm{~g}$ ( $5.15 \mathrm{mmol})$ of compound 7 was dissolved in $50 \mathrm{ml}$ of THF and $0.66 \mathrm{~g}(20.6 \mathrm{mmol})$ of elemental sulfur powder was added to the solution using solid addition apparatus. The suspension was sonicated for 6 hours at $40{ }^{\circ} \mathrm{C}$. The solution transitioned from pale yellow to an intense yellow. The solvent was removed in vacuo to form a yellow powder, which was then dissolved in $10 \mathrm{ml}$ of toluene, then warmed (to $\sim 35^{\circ} \mathrm{C}$ ) and filtered through Celite. The recrystallisation of the product was achieved by layering the solution with $20 \mathrm{~mL}$ of hexane, resulting in the formation of large yellow crystals. Yield: $3.28 \mathrm{~g}(4.386 \mathrm{mmol}), 85 \%$. m.p. $118{ }^{\circ} \mathrm{C}$. Analysis, found (calc. for $\mathrm{C}_{30} \mathrm{H}_{56} \mathrm{~N}_{6} \mathrm{~S}_{4} \mathrm{Sn}$ ): C 48.33 (48.31); $\mathrm{H}$ 7.67 (7.91); $\mathrm{N} 11.06$ (11.08). ${ }^{1} \mathrm{H}$ NMR (300 MHz, $\left.\mathrm{C}_{6} \mathrm{D}_{6}\right)$ : $\delta_{\mathrm{H}} 1.02-2.26(\mathrm{~m}, 40 \mathrm{H}, \mathrm{Cy}-\mathrm{H}), 2.32\left(\mathrm{~s}, 12 \mathrm{H}, \mathrm{NMe}_{2}\right), 3.15(\mathrm{~m}, 2 \mathrm{H}$, $\left.\mathrm{NCHC}_{5} \mathrm{H}_{10}\right), 3.29\left(\mathrm{~m}, 2 \mathrm{H}, \mathrm{NCHC}_{5} \mathrm{H}_{10}\right) ;{ }^{13} \mathrm{C}\left\{{ }^{1} \mathrm{H}\right\} \mathrm{NMR}(75.5 \mathrm{MHz}$,

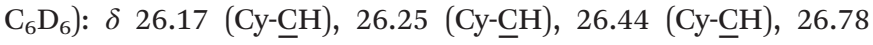

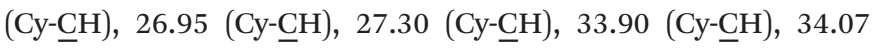
(Cy- $\underline{\mathrm{C}} \mathrm{H}), 35.74(\mathrm{Cy}-\underline{\mathrm{C}} \mathrm{H}), 38.08$ (Cy- $\left.\underline{\mathrm{CH}}), 40.19\left(\mathrm{~N}_{\left\{\underline{\mathrm{CH}}_{3}\right.}\right\}_{2}\right), 55.81$ $(\mathrm{N}-\underline{\mathrm{C}} \mathrm{H}), \quad 57.52(\mathrm{~N}-\underline{\mathrm{CH}}), \quad 167.54 \quad(\mathrm{~N}-\mathrm{C}-\mathrm{N}) ;{ }^{119}{ }^{\mathrm{Sn}}\left\{{ }^{1} \mathrm{H}\right\} \quad \mathrm{NMR}$ $\left(186.36 \mathrm{MHz}, \mathrm{C}_{6} \mathrm{D}_{6}\right): \delta_{\mathrm{Sn}}-383.0$.

Synthesis of 12. $2.10 \mathrm{~g}$ ( $3.39 \mathrm{mmol}$ ) of compound 7 was dissolved in $50 \mathrm{ml}$ of THF and $1.07 \mathrm{~g}(13.6 \mathrm{mmol})$ of elemental selenium powder was added to the solution and sonicated for 6 hours at $40^{\circ} \mathrm{C}$. The solution transitioned from pale yellow to an intense red. The solvent was removed in vacuo to form an orange powder, which was then dissolved in $10 \mathrm{ml}$ of toluene, warmed (to $\sim 35^{\circ} \mathrm{C}$ ) and filtered through Celite. The recrystallisation of the product was achieved by layering the solution with $20 \mathrm{ml}$ of hexane, resulting in large red crystals that were then used for analyses. Yield: $2.05 \mathrm{~g}(2.19 \mathrm{mmol}), 65 \%$. 
Analysis, found (calc. for $\mathrm{C}_{30} \mathrm{H}_{56} \mathrm{~N}_{6} \mathrm{Se}_{4} \mathrm{Sn}$ ): $\mathrm{C} 40.66$ (40.66); $\mathrm{H}$ 7.95 (7.99); $\mathrm{N} 9.86$ (9.88). ${ }^{1} \mathrm{H}$ NMR (300 MHz, $\left.\mathrm{C}_{6} \mathrm{D}_{6}\right): \delta_{\mathrm{H}}$ 0.77-2.58 (m, $40 \mathrm{H}, \mathrm{Cy}-\mathrm{H}), 2.70\left(\mathrm{~s}, 12 \mathrm{H}, \mathrm{NMe}_{2}\right), 3.13(\mathrm{~m}, 2 \mathrm{H}$, $\left.\mathrm{NCH}_{5} \mathrm{H}_{10}\right), \quad 3.25\left(\mathrm{~m}, \quad 2 \mathrm{H}, \quad \mathrm{NCHC}_{5} \mathrm{H}_{10}\right) ; \quad{ }^{13} \mathrm{C}\left\{{ }^{1} \mathrm{H}\right\} \quad \mathrm{NMR}$ (75.5 MHz, $\left.\mathrm{C}_{6} \mathrm{D}_{6}\right): \delta_{\mathrm{c}} 23.45(\mathrm{Cy}-\underline{\mathrm{CH}}), 24.13(\mathrm{Cy}-\underline{\mathrm{CH}}), 24.37(\mathrm{br}$,

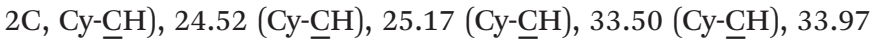
(br, 2C, Cy- $\underline{\mathrm{CH}}), 34.72(\mathrm{Cy}-\underline{\mathrm{CH}}), 38.50\left(\mathrm{~N}\left\{\underline{\mathrm{CH}}_{3}\right\}_{2}\right), 42.71(\mathrm{~N}-\underline{\mathrm{CH}})$, 54.31(N-CH), $166.05(\mathrm{~N}-\underline{\mathrm{C}}-\mathrm{N}) .{ }^{119} \mathrm{Sn}\left\{{ }^{1} \mathrm{H}\right\} \mathrm{NMR}(186.36 \mathrm{MHz}$, $\left.\mathrm{C}_{6} \mathrm{D}_{6}\right): \delta_{\mathrm{Sn}}-490.1 ;{ }^{77} \mathrm{Se}\left\{{ }^{1} \overline{\mathrm{H}}\right\}$ NMR $\left(95.34 \mathrm{MHz}, \mathrm{C}_{6} \mathrm{D}_{6}\right): \delta_{\text {Se }} 131.8$ $(\mathrm{s}), 567.7(\mathrm{~s})$.

Synthesis of 14. $1.06 \mathrm{~mL}(13.49 \mathrm{mmol})$ of propylene sulfide was added to a $40 \mathrm{~mL}$ solution of $7(1.62 \mathrm{~g}, 2.61 \mathrm{mmol})$ in hexane. The reaction mixture was allowed to stir for 4 days where the solution turns from colourless to a golden yellow. The solvent was removed in vacuo to form a golden yellow powder. The solid residue was dissolved in $15 \mathrm{ml}$ of warm toluene and filtered through a silica filter frit, then cooled to $-28{ }^{\circ} \mathrm{C}$ for 24 hours. The resulting pale yellow microcrystalline powder which formed, was isolated via cannula filtration and dried in vacuo. Yield: 1.23 g, 75\%. m.p: $149{ }^{\circ} \mathrm{C}$. Analysis, found (calc. for $\mathrm{C}_{30} \mathrm{H}_{56} \mathrm{~N}_{6} \mathrm{SSn}$ ): C 55.07 (55.30); $\mathrm{H} 9.03$ (8.66); N 12.30 (12.90). ${ }^{1} \mathrm{H}$ NMR (300 MHz, $\left.\mathrm{C}_{6} \mathrm{D}_{6}\right) \delta 0.77-2.08(\mathrm{~m}, 40 \mathrm{H}, \mathrm{Cy}-\mathrm{H})$, $2.69\left(\mathrm{~s}, 12 \mathrm{H}, \mathrm{NMe}_{2}\right), 3.44\left(\mathrm{~m}, 2 \mathrm{H}, \mathrm{NCHC}_{5} \mathrm{H}_{10}\right), 3.57(\mathrm{~m}, 2 \mathrm{H}$, $\left.\mathrm{NCH}_{-} \mathrm{H}_{5} \mathrm{H}_{10}\right) .{ }^{13} \overline{\mathrm{C}}\left\{{ }^{1} \mathrm{H}\right\} \quad$ NMR- $\left(\mathrm{C}_{6} \mathrm{D}_{6}\right) \quad \overline{24.87}$ (Cy- $\left.\underline{\mathrm{CH}}\right) \quad 25.58$

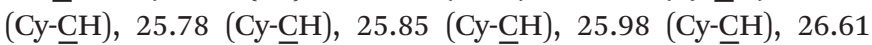

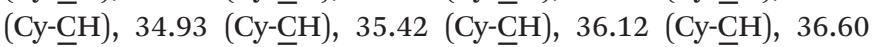
$(\mathrm{Cy}-\underline{\mathrm{C}} \mathrm{H}), 39.88\left(\mathrm{~N}\left\{\underline{\mathrm{CH}}_{3}\right\}_{2}\right), 53.65(\mathrm{~N}-\underline{\mathrm{C}} \mathrm{H}), 55.74(\mathrm{~N}-\underline{\mathrm{CH}}), 165.39$ $(\mathrm{N}-\mathrm{C}-\mathrm{N}) .{ }^{119} \mathrm{Sn}\left\{{ }^{1} \mathrm{H}\right\}$ NMR $\left(186.36 \mathrm{MHz}, \mathrm{C}_{6} \mathrm{D}_{6}\right) \delta_{\mathrm{Sn}}-248.0$

Synthesis of $15.0 .53 \mathrm{~g}(2.67 \mathrm{mmol})$ of $\mathrm{Et}_{3}$ PSe in $20 \mathrm{ml} \mathrm{THF}$ was added to $1.23 \mathrm{~g}$ ( $2.67 \mathrm{mmol})$ of compound 6 dissolved in $40 \mathrm{ml}$ of THF via cannula transfer. The solution was stirred for 4 hours during which time the solution changed colour from colourless to an intense yellow colour. The volatile materials were removed in vacuo, forming a yellow powder, which was then extracted into in $15 \mathrm{ml}$ of warm toluene, and filtered through Celite. Recrystallisation at $-28{ }^{\circ} \mathrm{C}$ resulted in the formation of large yellow/orange crystals. Yield: $1.03 \mathrm{~g}$ (1.25 mmol), 72\%. m.p. $124{ }^{\circ} \mathrm{C}$. Analysis, found (calc. for $\mathrm{C}_{18} \mathrm{H}_{40} \mathrm{~N}_{6} \mathrm{SeSn}$ ): C 44.20 (44.00); H 7.97 (8.21); N 16.70 (17.11). ${ }^{1} \mathrm{H}$ NMR (300 MHz, $\left.\mathrm{CD}_{2} \mathrm{Cl}_{2}\right): \delta_{\mathrm{H}} 1.34\left(\mathrm{br}, \mathrm{m}, 12 \mathrm{H}, \mathrm{CHMe}_{2}\right)$, 1.41 (br, m, $\left.12 \mathrm{H}, \mathrm{CHMe}_{2}\right) 2.93$ (s, 12H, $\underline{\mathrm{NM}}_{2}$ ), 3.88 (br, m, $\left.4 \mathrm{H}, \mathrm{CHMe}_{2}\right) .{ }^{13} \mathrm{C}\left\{{ }^{1} \mathrm{H}\right\} \mathrm{NMR}\left(75.5 \mathrm{MHz}, \overline{\mathrm{CD}}_{2} \mathrm{Cl}_{2}\right): \delta_{\mathrm{c}} 23.69$ $(\mathrm{CHMe} 2), 23.78\left(\underline{\mathrm{CHMe}}_{2}\right), 24.80\left(\underline{\mathrm{CHMe}}_{2}\right), 25.16\left(\mathrm{CHMe}_{2}\right), 25.16$ $(\mathrm{CHMe} 2), 40.62\left(\underline{\mathrm{NMe}}_{2}\right), 47.51(\underline{\mathrm{CHMe}}), 48.93(\underline{\mathrm{CHMe}}) 166.30$ $(\mathrm{N}-\mathrm{C}-\mathrm{N}) .{ }^{119} \mathrm{Sn}\left\{{ }^{1} \mathrm{H}\right\}$ NMR $\left(186.36 \mathrm{MHz}, \mathrm{CD}_{2} \mathrm{Cl}_{2}\right): \delta_{\mathrm{Sn}}-779.0$ $\left({ }^{1} J^{119}{ }_{\mathrm{Sn}-77} \mathrm{Se}=1329 \mathrm{~Hz}\right) ;{ }^{77} \mathrm{Se}\left\{{ }^{1} \mathrm{H}\right\} \mathrm{NMR}\left(95.34 \mathrm{MHz}, \mathrm{CDCl}_{3}\right): \delta_{\mathrm{Se}}$ -787 .

Synthesis of 16. $0.53 \mathrm{~g}(2.67 \mathrm{mmol})$ of $\mathrm{Et}_{3}$ PSe in $20 \mathrm{ml} \mathrm{THF}$ was added to $0.53 \mathrm{~g}(2.67 \mathrm{mmol})$ of compound 7 dissolved in $40 \mathrm{ml}$ of THF via cannula transfer. The solution was stirred for 4 hours during which time the solution changed colour from pale yellow to an intense yellow/orange colour. The volatile materials were removed in vacuo, forming a yellow powder, which was then extracted into in $15 \mathrm{ml}$ of warm toluene, and filtered through Celite. Recrystallisation at $-28{ }^{\circ} \mathrm{C}$ resulted in the formation of large yellow/orange crystals. Yield: $1.66 \mathrm{~g}$
(2.67 mmol), 89\%. m.p. $114{ }^{\circ} \mathrm{C}$. Analysis, found (calc. for $\mathrm{C}_{30} \mathrm{H}_{56} \mathrm{~N}_{6} \mathrm{SeSn}$ ): C 51.55 (51.59); H 8.12 (8.08); N 12.00 (12.03). ${ }^{1} \mathrm{H}$ NMR $\left(300 \mathrm{MHz}, \mathrm{C}_{6} \mathrm{D}_{6}\right): \delta_{\mathrm{H}} 0.99-2.28(\mathrm{~m}, 40 \mathrm{H}, \mathrm{Cy}-\mathrm{H}), 2.34$ $\left(\mathrm{s}, 12 \mathrm{H}, \mathrm{NMe}_{2}\right), 3.14\left(\mathrm{~m}, 2 \mathrm{H}, \mathrm{NCHC}_{5} \mathrm{H}_{10}\right), 3.36(\mathrm{~m}, 2 \mathrm{H}$, $\left.\mathrm{NCHC}_{5} \mathrm{H}_{10}\right) ;{ }^{13} \mathrm{C}\left\{{ }^{1} \mathrm{H}\right\}$ NMR $\left(75.5 \mathrm{MHz}, \mathrm{C}_{6} \mathrm{D}_{6}\right): \delta_{\mathrm{c}} 24.41(\mathrm{Cy}-\underline{\mathrm{CH}})$,

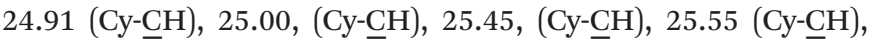

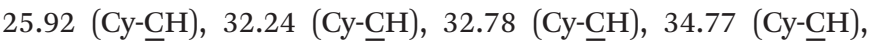
36.81 ( $\mathrm{Cy}-\underline{\mathrm{CH}}), 38.80\left(\mathrm{~N}\left(\underline{\mathrm{CH}}_{3}\right)_{2}\right), 54.46(\mathrm{~N}-\underline{\mathrm{CH}}), 56.22(\mathrm{~N}-\underline{\mathrm{CH}})$, $167.7(\mathrm{~N}-\underline{\mathrm{C}}-\mathrm{N}) .{ }^{119} \mathrm{Sn}\left\{{ }^{1} \mathrm{H}\right\} \mathrm{NMR}\left(186.36 \mathrm{MHz}, \mathrm{C}_{6} \mathrm{D}_{6}\right): \delta_{\mathrm{Sn}}-\overline{5} 66.3$ ${ }^{77} \mathrm{Se}\left\{{ }^{1} \mathrm{H}\right\} \mathrm{NMR}\left(95.34 \mathrm{MHz}, \mathrm{C}_{6} \mathrm{D}_{6}\right): \delta_{\mathrm{Se}}-476.01$

Synthesis of $17.0 .60 \mathrm{~g}(1.30 \mathrm{mmol})$ of compound 6 was dissolved in $50 \mathrm{ml}$ of THF and $0.20 \mathrm{~g}(1.50 \mathrm{mmol})$ of elemental tellurium powder was added to the solution and sonicated for 6 hours at $40{ }^{\circ} \mathrm{C}$. The solution transitioned from pale yellow to an intense red. The solvent was removed in vacuo to form a red powder, which was then dissolved in $10 \mathrm{ml}$ of toluene, warmed (to $\sim 35^{\circ} \mathrm{C}$ ) and filtered through Celite. The recrystallisation of the product was achieved by layering the solution with $20 \mathrm{~mL}$ of hexane, resulting in large red crystals that were then used for analyses. Note: The compound immediately decomposes to a black powder when exposed to air or heated above $71{ }^{\circ} \mathrm{C}$ under argon. Yield: $0.55 \mathrm{~g}$ (0.93 mmol), 72\%. decomp. $71^{\circ} \mathrm{C}$. Analysis, found (calc. for $\mathrm{C}_{18} \mathrm{H}_{40} \mathrm{~N}_{6} \mathrm{TeSn}$ ): C 36.82 (36.84); $\mathrm{H}$ 6.87 (6.87); N 14.39 (14.32). ${ }^{1} \mathrm{H}$ NMR (300 MHz, d $\left.{ }^{8}-\mathrm{THF}\right): \delta_{\mathrm{H}}$ $1.46\left(\mathrm{~m}, 24 \mathrm{H}, \mathrm{CHMe}_{2}\right), 2.29\left(\mathrm{~s}, 12 \mathrm{H}, \mathrm{NMe}_{2}\right), 3.80(\mathrm{~m}, 4 \mathrm{H}$, $\left.\mathrm{CHMe}_{2}\right) .{ }^{13} \mathrm{C}\left\{{ }^{1} \mathrm{H}\right\}$ NMR (75.5 MHz, d $\left.{ }^{8}-\mathrm{THF}\right): \delta_{\mathrm{c}} 24.23(\mathrm{br}$, $\left.\mathrm{CH}^{-} \underline{\mathrm{He}}_{2}\right), 39.61\left(\mathrm{NMe}_{2}\right), 48.1$ ( $\left.\underline{\mathrm{C}} \underline{\mathrm{HMe}}_{2}\right) 167.50(\mathrm{~N}-\underline{\mathrm{C}}-\mathrm{N}) .{ }^{119} \mathrm{Sn}$ $\left\{{ }^{1} \mathrm{H}\right\}$ NMR $\left(186.36 \overline{\mathrm{MHz}}, \mathrm{d}^{8}-\mathrm{THF}\right): \delta_{\mathrm{Sn}}-919.7,{ }^{125} \mathrm{Te}\left\{{ }^{1} \mathrm{H}\right\} \mathrm{NMR}$ $\left(157.98 \mathrm{MHz}, \mathrm{C}_{6} \mathrm{D}_{6}\right): \delta_{\mathrm{Te}}-792 \mathrm{ppm}\left({ }^{1} J_{125 \mathrm{Te}-119} \mathrm{Sn}=7773 \mathrm{~Hz}\right)$.

Synthesis of 18. $2.43 \mathrm{~g}$ ( $3.92 \mathrm{mmol})$ of compound 7 was dissolved in $50 \mathrm{ml}$ of THF and $0.60 \mathrm{~g}(4.72 \mathrm{mmol})$ of elemental tellurium powder was added to the solution and sonicated for 6 hours at $40{ }^{\circ} \mathrm{C}$. The solution transitioned from pale yellow to an intense red. The solvent was removed in vacuo to form a red powder, which was then dissolved in $10 \mathrm{ml}$ of toluene, warmed (to $\sim 35{ }^{\circ} \mathrm{C}$ ) and filtered through Celite. The recrystallisation of the product was achieved by layering the solution with $20 \mathrm{ml}$ of hexane, resulting in large red crystals. Yield: $2.51 \mathrm{~g}$ (3.37 mmol), 86\%. decomp. $107^{\circ} \mathrm{C}$. Analysis, found (calc. for $\mathrm{C}_{30} \mathrm{H}_{56} \mathrm{~N}_{6} \mathrm{SnTe}$ ): C 42.52 (42.52); H 6.76 (6.71); N 8.58 (8.49). ${ }^{1} \mathrm{H}$ NMR (300 MHz, $\left.\mathrm{C}_{6} \mathrm{D}_{6}\right): \delta_{\mathrm{H}} 0.78-2.03(\mathrm{~m}, 40 \mathrm{H}, \mathrm{Cy}), 2.38(\mathrm{~s}$, $\left.12 \mathrm{H}, \quad \underline{\mathrm{Me}}_{2}\right), \quad 3.52\left(\mathrm{~m}, \quad 4 \mathrm{H}, \quad \mathrm{NCHC}_{5} \mathrm{H}_{10}\right) .{ }^{13} \mathrm{C} \quad\left\{{ }^{1} \mathrm{H}\right\} \quad \mathrm{NMR}$ (75.5 MHz, $\left.\mathrm{C}_{6} \mathrm{D}_{6}\right): \delta_{\mathrm{c}} 26.14(\mathrm{Cy}-\underline{\mathrm{CH}}), 26.95(\mathrm{Cy}-\underline{\mathrm{CH}}), 30.2$ (Cy$\underline{\mathrm{CH}}), 39.9\left(\mathrm{~N}\left(\mathrm{CH}_{3}\right)_{2}\right), 56.87(\mathrm{~N}-\mathrm{C}(\mathrm{H})), 167.33(\overline{\mathrm{N}}-\mathrm{C}-\mathrm{N}) .{ }^{119} \mathrm{Sn}$ $\left\{{ }^{1} \mathrm{H}\right\}$ NMR $\left(186.36 \mathrm{MHz}, \mathrm{C}_{6} \mathrm{D}_{6}\right): \delta_{\mathrm{Sn}}-818 \mathrm{ppm}(\mathrm{s}) ;{ }^{125} \mathrm{Te}\left\{{ }^{1} \mathrm{H}\right\}$ NMR (157.98 MHz, $\left.\mathrm{C}_{6} \mathrm{D}_{6}\right): \delta_{\mathrm{Te}}-1259 \mathrm{ppm}$.

\section{Single crystal X-ray diffraction studies}

Experimental details relating to the single-crystal X-ray crystallographic studies for compounds 7, 8, 10, 11, 12, 13, 15, 16, 17 and $\mathbf{1 8}$ are summarised in Tables S6 and S7 (ESI ). Single Crystal X-ray crystallography data were collected at $150 \mathrm{~K}$ on Nonius Kappa CCD diffractometers equipped with low temperature devices, using graphite monochromated Mo K $\alpha$ radiation $(\lambda=0.71073 \AA)$. The data collected by the diffractometers were processed using the Nonius Software. Structure solution, 
followed by full matrix least-squares refinement, was performed using either the WinGX-170 suite of programs or the program suite X-SEED. Crystals were isolated from argon filled Schlenk flask and immersed under oil before being mounted onto the diffractometer.

\section{Aerosol assisted chemical vapour deposition (AA-CVD) procedure}

The precursor solution is prepared within a glove box under an atmosphere of argon and all solvents are dried and degassed prior to preparation. The precursor holder is kept under an atmosphere of argon, sealed and attached onto to the AA-CVD apparatus. Once all substrates were prepared and mounted into the deposition chamber, argon gas is allowed to flow through the system, bi-passing the precursor holder, for 20 minutes in order to purge the system with argon. Then with continuing gas flow the hot-wall furnace is switched on and allowed to reach the target deposition temperature and equilibrate for 20 minutes. Once this is achieved the gas flow is diverted to flow via the precursor solution which draws the solution into the TSI 3076 Constant Output Atomiser and out into the deposition chamber where the deposition commences and the timer is started. Gas flow is monitored via bubbler and gas pressure fixed 10 bar until it reaches the atomiser. A diagram of the AA-CVD apparatus is included in the ESI.

\section{Thermogravimetric analysis (TGA)}

TGA was collected using a TGA 4000 PerkinElmer system. Samples were prepared air sensitively using a crimped aluminium sample pan. TGA's were performed under a flow of $\mathrm{N}_{2}$ at $20 \mathrm{ml} \mathrm{min}{ }^{-1}$ and heated from $30{ }^{\circ} \mathrm{C}$ to $600{ }^{\circ} \mathrm{C}$ at a ramp rate of $5^{\circ} \mathrm{C} \min ^{-1}$.

\section{Powder X-ray diffractometry (pXRD)}

pXRD data was collected on a BRUKER D8-Advance. The X-ray diffraction spectra were collected for the thin films using the flat plate mode from 5 to $702 \theta$ at $2^{\circ}$ per minute. X-rays were generated from a Cu source at wave lengths of $1.54 \AA$.

\section{Scanning electron microscopy (SEM)}

SEM was performed to visualise the morphology of the films both as cross sections (using a Field Emission Scanning Electron Microscope 6301F) and top down (JEOL 6480 Low Vacuum large stage SEM platform) images. The films were prepared by mounting onto steel SEM mounts with conductive carbon tape attached to the bottom and top surface of the films, to maximise conductivity of electrons and prevent charge accumulation. Samples were desiccated at $35{ }^{\circ} \mathrm{C}$ for 24 hours prior to analysis.

\section{Atomic force microscopy (AFM)}

AFM analysis was performed using a Digital Instruments Nanoscope IIIa, with BRUKER SNL-10 Silicon on Nitride Lever contact tips (tip radius $<10 \mathrm{~nm}, f_{0}: 50-80 \mathrm{kHz}, k: 0.350 \mathrm{~N} \mathrm{~m}^{-1}$ and $T: 600 \mathrm{~nm}$ ), in contact mode. Images processed using the open access Gwyddion SPM data analyser.

\section{Energy dispersive X-ray spectroscopy (EDS)}

EDS was performed using Oxford Instruments Scanning Electron Microscope $6480 \mathrm{LV}$ and processed on INCA Wave software. All spectra were standardised and calibrated against a standard silicon wafer sample. The magnification, working distance and beam energy (10 keV) were kept consistent between spectral analyses.

\section{Raman spectroscopy}

Raman spectra were collected using a Renishaw inVia Raman Microscope fitted with a $532 \mathrm{~nm}$ laser at a $10 \%$ spot size, $3 \mathrm{~s}$ exposure time and 1\% energy intensity. The data was processed using a Renishaw WiRE software package.

\section{Conflicts of interest}

There are no conflicts to declare.

\section{Acknowledgements}

The authors thank EPSRC for funding (EP/L0163541 and EP/ G03768X/1) and the Doctoral Training Centre in Sustainable Chemical Technologies for a PhD studentship (I. Y. A).

\section{References}

1 M. Zhou, G. J. Snyder, L. Li and L.-D. Zhao, Inorg. Chem. Front., 2016, 3, 1449-1463.

2 Z. Wang, P. K. Nayak, J. A. Caraveo-Frescas and H. N. Alshareef, Adv. Mater., 2016, 28, 3831-3892.

3 D. J. Lewis, P. Kevin, O. Bakr, C. A. Muryn, M. A. Malik and P. O’Brien, Inorg. Chem. Front., 2014, 1, 577.

4 O. Madelung, Semiconductors: Data Handbook, Springer, Berlin, London, 2004.

5 A. de Kergommeaux, J. Faure-Vincent, A. Pron, R. de Bettignies, B. Malaman and P. Reiss, J. Am. Chem. Soc., 2012, 134, 11659-11666.

6 Y. Yin and A. P. Alivisatos, Nature, 2005, 437, 664-670.

7 M. Yarema, R. Caputo and M. V. Kovalenko, Nanoscale, 2013, 5, 8398.

8 D. V. Talapin, J.-S. Lee, M. V. Kovalenko and E. V. Shevchenko, Chem. Rev., 2010, 110, 389-458.

9 P. Marchand and C. J. Carmalt, Coord. Chem. Rev., 2013, 257, 3202-3221.

10 I. Y. Ahmet, M. S. Hill, A. L. Johnson and L. M. Peter, Chem. Mater., 2015, 27, 7680-7688.

11 I. Barbul, A. L. Johnson, G. Kociok-Kohn, K. C. Molloy, C. Silvestru and A. L. Sudlow, ChemPlusChem, 2013, 78, 866-874.

12 T. Wildsmith, M. S. Hill, A. L. Johnson, A. J. Kingsley and K. C. Molloy, Chem. Commun., 2013, 49, 8773-8775.

13 A. L. Catherall, S. Harris, M. S. Hill, A. L. Johnson and M. F. Mahon, Cryst. Growth Des., 2017, 17, 5544-5551. 
14 C. A. Stewart, D. A. Dickie, Y. Tang and R. A. Kemp, Inorg. Chim. Acta, 2011, 376, 73-79.

15 L. R. Sita, J. R. Babcock and R. Xi, J. Am. Chem. Soc., 1996, 118, 10912-10913.

16 C. A. Stewart, D. A. Dickie, M. V. Parkes, J. A. Saria and R. A. Kemp, Inorg. Chem., 2010, 49, 11133-11141.

17 W. J. Baumgardner, J. J. Choi, Y.-F. Lim and T. Hanrath, J. Am. Chem. Soc., 2010, 132, 9519-9521.

18 S. R. Foley, G. P. A. Yap and D. S. Richeson, Polyhedron, 2002, 21, 619-627.

19 M. Brym, M. D. Francis, G. X. Jin, C. Jones, D. P. Mills and A. Stasch, Organometallics, 2006, 25, 4799-4807.

20 S. P. Green, C. Jones, K. A. Lippert, D. P. Mills and A. Stasch, Inorg. Chem., 2006, 45, 7242-7251.

21 T. Chlupaty, Z. Padelkova, F. DeProft, R. Willem and A. Ruzicka, Organometallics, 2012, 31, 2203-2211.

22 T. Chlupaty, Z. Padelkova and A. Ruzicka, Main Group Met. Chem., 2014, 37, 49-52.

23 M. K. Barman, A. Baishya, T. Peddarao and S. Nembenna, J. Organomet. Chem., 2014, 772, 265-270.

24 T. Chlupaty, Z. Ruzickova, M. Horacek, J. Merna, M. Alonso, F. De Proft and A. Ruzicka, Organometallics, 2015, 34, 2202-2211.

25 T. Chlupatý, Z. Padělková, F. DeProft, R. Willem and A. Růžička, Organometallics, 2012, 31, 2203-2211.

26 R. E. Abutbul, E. Segev, S. Samuha, L. Zeiri, V. Ezersky, G. Makov and Y. Golan, CrystEngComm, 2016, 18, 1918-1923.

27 H.-X. Yeong, H.-W. Xi, Y. Li, S. B. Kunnappilly, B. Chen, K.-C. Lau, H. Hirao, K. H. Lim and C.-W. So, Chem. - Eur. J., 2013, 19, 14726-14731.

28 N. Nimitsiriwat, V. C. Gibson, E. L. Marshall, A. J. P. White, S. H. Dale and M. R. J. Elsegood, Dalton Trans., 2007, 4464.

29 K. Phomphrai, C. Pongchan-o, W. Thumrongpatanaraks, P. Sangtrirutnugul, P. Kongsaeree and M. Pohmakotr, Dalton Trans., 2011, 40, 2157-2159.

30 M. M. Olmstead and P. P. Power, Inorg. Chem., 1984, 23, 413-415.

31 N. Tokitoh, T. Matsumoto and R. Okazaki, Tetrahedron Lett., 1992, 33, 2531-2534.

32 Y. Matsuhashi, N. Tokitoh, R. Okazaki, M. Goto and S. Nagase, Organometallics, 1993, 12, 1351-1358.

33 Y. L. Zhou and D. S. Richeson, J. Am. Chem. Soc., 1996, 118, 10850-10852.

34 R. Okazaki, M. Saito and N. Tokitoh, Phosphorus, Sulfur Silicon Relat. Elem., 1997, 124, 363-370.

35 M. Saito, N. Tokitoh and R. Okazaki, J. Am. Chem. Soc., 1997, 119, 11124-11125.

36 S. R. Foley, G. P. A. Yap and D. S. Richeson, Organometallics, 1999, 18, 4700-4705.

37 L. Pauling, The Nature of the Chemical Bond and the Structure of Molecules and Crystals : An Introduction to Modern Structural Chemistry, Cornell University Press, New York, 1960.
38 T. Tajima, N. Takeda, T. Sasamori and N. Tokitoh, Organometallics, 2006, 25, 3552-3553.

39 N. Tokitoh, H. Suzuki, T. Matsumoto, Y. Matsuhashi, R. Okazaki and M. Goto, J. Am. Chem. Soc., 1991, 113, 7047-7049.

40 M. K. Barman and S. Nembenna, RSC Adv., 2016, 6, 338345.

41 T. Matsumoto, Y. Matsui, Y. Nakaya and K. Tatsumi, Chem. Lett., 2001, 60-61.

42 M. K. Barman and S. Nembenna, RSC Adv., 2016, 6, 338-345.

43 M. C. Kuchta and G. Parkin, J. Am. Chem. Soc., 1994, 116, 8372-8373.

44 W.-P. Leung, W.-H. Kwok, L. T. C. Law, Z.-Y. Zhou and T. C. W. Mak, Chem. Commun., 1996, 505-506.

45 W.-P. Leung, W.-H. Kwok, Z.-Y. Zhou and T. C. W. Mak, Organometallics, 2000, 19, 296-303.

46 B. Mairychová, L. Dostál, A. Růžička, M. Fulem, K. Růžička, A. Lyčka and R. Jambor, Organometallics, 2011, 30, 5904-5910.

47 L. S. Price, I. P. Parkin, T. G. Hibbert and K. C. Molloy, Chem. Vap. Deposition, 1998, 4, 222-225.

48 I. P. Parkin, L. S. Price, T. G. Hibbert and K. C. Molloy, J. Mater. Chem., 2001, 11, 1486-1490.

49 B. P. Bade, S. S. Garje, Y. S. Niwate, M. Afzaal and P. O’Brien, Chem. Vap. Deposition, 2008, 14, 292-295.

50 P. Kevin, D. J. Lewis, J. Raftery, M. Azad Malik and P. O’Brien, J. Cryst. Growth, 2015, 415, 93-99.

51 M. A. Buckingham, A. L. Catherall, M. S. Hill, A. L. Johnson and J. D. Parish, Crys. Growth Des., 2017, 17, 907-912.

52 J. Liu, P. Kopold, C. Wu, P. A. van Aken, J. Maier and Y. Yu, Energy Environ. Sci., 2015, 8, 3531-3538.

53 A. K. Sinha, A. Sil, A. K. Sasmal, M. Pradhan and T. Pal, New J. Chem., 2015, 39, 1685-1690.

54 D.-H. Lee and C.-M. Park, ACS Appl. Mater. Interfaces, 2017, 9, 15439-15448.

55 J. Wu, Z. Hu, Z. Jin, S. Lei, H. Guo, K. Chatterjee, J. Zhang, Y. Yang, B. Li, Y. Liu, J. Lai, R. Vajtai, B. Yakobson, M. Tang, J. Lou and P. M. Ajayan, Adv. Mater. Interfaces, 2016, 3, 1600383.

56 H. S. Im, Y. Myung, Y. J. Cho, C. H. Kim, H. S. Kim, S. H. Back, C. S. Jung, D. M. Jang, Y. R. Lim, J. Park and J.-P. Ahn, RSC Adv., 2013, 3, 10349.

57 F. Izumi, J. Solid State Chem., 1981, 38, 381-385.

58 J. P. Coyle, P. A. Johnson, G. A. DiLabio, S. T. Barry and J. Müller, Inorg. Chem., 2010, 49, 2844-2850.

59 J. P. Coyle, W. H. Monillas, G. P. A. Yap and S. T. Barry, Inorg. Chem., 2008, 47, 683-689.

60 T. Kim, Y. Yao, J. P. Coyle, S. T. Barry and F. Zaera, Chem. Mater., 2013, 25, 3630-3639.

61 Q. Ma, H. Guo, R. G. Gordon and F. Zaera, Chem. Mater., 2011, 23, 3325-3334.

62 I. Y. Ahmet, J. R. Thompson, M. S. Hill, G. Kociok-Köhn and A. L. Johnson, Eur. J. Inorg. Chem., 2017, DOI: 10.1002/ ejic. 201800071. 